University at Buffalo School of Law

Digital Commons @ University at Buffalo School of Law

\title{
The Administrative Law of Global Private-Public Regulation: the Case of Forestry
}

\author{
Errol E. Meidinger \\ University at Buffalo School of Law
}

Follow this and additional works at: https://digitalcommons.law.buffalo.edu/journal_articles

Part of the Environmental Law Commons

\section{Recommended Citation}

Errol E. Meidinger, The Administrative Law of Global Private-Public Regulation: the Case of Forestry, 17 Eur. J. Int'I L. 47 (2006).

Available at: https://digitalcommons.law.buffalo.edu/journal_articles/553

This is a pre-copyedited, author-produced PDF of an article accepted for publication in European Journal of International Law following peer review. The version of record 17 Eur. J. Int'I L. 47 (2006) is available online at: https://doi.org/10.1093/ejil/chi168.

\section{IN COPYRIGHT}

This Article is brought to you for free and open access by the Faculty Scholarship at Digital Commons @ University at Buffalo School of Law. It has been accepted for inclusion in Journal Articles by an authorized administrator of Digital Commons @ University at Buffalo School of Law. For more information, please contact lawscholar@buffalo.edu. 


\title{
The Administrative Law of Global Private-Public Regulation: the Case of Forestry
}

\author{
Errol Meidinger*
}

\begin{abstract}
An important ensemble of transnational, transgovernmental regulatory institutions has emerged in the forestry sector over the past decade. These 'forest certification' programmes set global standards for proper forest management and apply them through institutionalized licensing and inspection programmes. Similar programmes are appearing in other sectors. Developed largely by environmental NGOs and industry associations rather than governments, forest certification programmes are nominally voluntary, but are becoming increasingly mandatory in practice. They are also gradually linking with government regulatory and management programmes in various ways, while remaining in tension both with each other and with government programmes. The overall regulatory system is thus highly dynamic, as the programmes compete with each other for business and also with government regulatory programmes for public acceptance. This paper describes and assesses the administrative law - i.e., the requirements for rule-making and rule application - of the emerging global forest regulatory system. It finds that while the certification programmes are becoming increasingly transparent and participatory, often comparing favourably with government programmes, some of them still need considerable improvement and all of them face serious challenges. It concludes with a discussion of the problem of accountability,
\end{abstract}

* Professor and Vice Dean of Law for Research, Adjunct Professor of Sociology, State University of New York at Buffalo, USA and Honorary Professor of Forestry and Environmental Science, University of Freiburg, Germany. Email: eemeid@buffalo.edu. Paper prepared for the conference on 'Global Administrative Law: National and International Accountability Mechanisms for Global Regulatory Governance, New York University Law School, 22-23 April 2005, and also presented to the London School of Economics Center for the Analysis of Risk and Regulation, 31 May 2005. A preliminary version of the argument was presented to faculty seminars at Melbourne, Monash and Australian National Universities in May 2003. The author is grateful for comments received at each of the presentations as well as additional comments from Bill Anderson, Tim Bartley, Julia Black, Barry Boyer, Tim Cadman, Ben Cashore, Michael Dowdle, Chris Elliott, Lise Gelernter, Benedict Kingsbury, Nico Krisch, Martin Lodge, Michael Power, Aseem Prakash, Chuck Sabel, Colin Scott, Margaret Shannon, Peter Sprang, and Matthew Wenban-Smith. Thanks go also to Richard Stewart for the invitation to write this paper and to the Baldy Center for Law and Social Policy of the State University of New York in Buffalo for research support. 
outlining the possibility that the programmes exemplify an emerging new kind of 'learning accountability'.

\section{Introduction}

Although few things would seem to be more local than trees, an extensive global system of forestry regulation is under construction. Its main architects are not governments or intergovernmental organizations, although they occasionally perform important tasks. Instead, transnational environmental organizations, in concert with a small but growing number of business, labour, social justice, landowner and professional groups, have been the primary designers of emerging global forestry institutions. These groups have established mutually interested alliances that cooperate and compete with each other in complex and shifting ways, and that regularly engage in reciprocal observation, communication, lobbying and policy adjustment with governmental and intergovernmental agencies. The overall system of forestry regulation is thus a multi-centred private/public one, which operates in a loosely coordinated and sometimes disjointed fashion. One could therefore also legitimately call it a governance system, since it articulates and adapts guiding norms through a system of shared authority; ${ }^{1}$ or it could be called a regime, since it involves multiple institutions operating in terms of common principles, rules, procedures and programmes. ${ }^{2}$ In order to highlight the principles and rules governing these processes, however, this paper treats the system as one of regulation, and indeed of regulatory law-making. ${ }^{3}$ This perspective also seems to be appropriate as an empirical matter, since much of the system is concentrated on the development of general rules and their application to categories of enterprises by specialized officials relying on normative justifications and background threats of sanctions. ${ }^{4}$

For the past decade a major institutional focus of this emergent system has been 'forest certification', wherein experts certify to a broader public that specific forestry

1 See generally, A.C. Cutler, V. Haufler, and T. Porter (eds), Private Authority in International Affairs (1999); J.N. Rosenau and E.-O. Czempiel (eds), Governance Without Government: Order and Change in World Politics (1992); Cashore, 'Legitimacy and the Privatization of Environmental Governance: How Non-State Market-Driven (NSMD) Governance Systems Gain Rule-Making Authority’, 15 Governance (2002) 503; Burns, Drahos, and Shearing, 'Nodal Governance', 30 Australian J Legal Philosophy (2005) 30.

2 Gulbrandsen, 'Overlapping Public and Private Governance: Can Forest Certification Fill the Gaps in the Global Forest Regime?', 4 Global Environmental Politics (2004) 75; Levy, Young, and Zürn, 'The Study of International Regimes', 1 European J Int'l Relations (1995) 267.

3 I call it a 'system' because the various parts, although operating at different levels and sometimes with different constituencies and goals, are dependent on and adapt to each other in ways that orient their overall activity. This is different from the concept of a legal system as it is sometimes used to refer to a set of rules and assumptions that are logically consistent with each other and perhaps derived from the same source of authority. My concept of system is more akin to an ecological than to a logical or mechanical one.

4 For a more detailed exposition of forest certification as a form of law making, see Meidinger, 'Forest Certification as Environmental Law Making by Global Civil Society', in E. Meidinger, C. Elliott, and G. Oesten (eds), Social and Political Dimensions of Forest Certification (2003). 
operations meet applicable standards for proper forest management. Were it done by governments, forest certification would readily be seen by legal scholars as administrative licensing or permitting and the larger system of policy-making and implementation as administrative regulation. ${ }^{5}$ Because forest certification is more fragmented and decentralized than most government regulation, understanding it requires forsaking simplistic source-of-law models for understanding administrative law.

Forest certification is also connected to parallel developments in other sectors, including organic agriculture, ${ }^{6}$ fisheries, ${ }^{7}$ mining, ${ }^{8}$ coffee, ${ }^{9}$ and others, although it appears to be a leading edge in many ways. This paper thus treats forest certification both as an indicator of broader trends in the administrative law of global governance, ${ }^{10}$ and as a place from which to trace connections to other regulatory domains. Focusing on the administrative law of forest certification is entirely apt not only from an external perspective, but also from an internal one, because much of the system is in fact defined and structured in terms of classical administrative law issues and practices. The next two subsections describe the historical emergence of the global forestry regulatory system and the primary actors involved in forest certification. Sections 2 and 3 describe its rule-making and adjudicatory policies and practices. Finally, Section 4 offers some preliminary assessments of the effectiveness, reliability and accountability of the emerging global regulatory system. It suggests that forest certification has triggered significant changes in forest management practices that are likely to expand, that its reliance on certifiers paid by the firms being certified is fragile, and that a new, partially inchoate accountability structure focused on mutually adjusting institutions and normative standards is emerging. Ultimately, if these developments continue, they may demand a major rethinking of the basis of political legitimacy in transnational regulation.

\section{A Historical Context}

The movement for forest certification grew out of the 'tropical timber crisis' of the mid-1980s, when environmental organizations portrayed the rapid deforestation of

5 Indeed, corporate managers often refer to a 'social licence to operate', and forest certification may be one effort to institutionalize such licences in forestry: see, e.g., Gunningham, Kagan, and Thornton, 'Social License and Environmental Protection: Why Businesses go Beyond Compliance', 29 Law and Social Inquiry (2004) 307.

6 International Federation of Organic Agriculture Movements (IFOAM), available at http:// www.ifoam.org/.

Marine Stewardship Council, available at http://www.msc.org.

Mining Certification Evaluation Project, available at http://www.minerals.csiro.au/sd/SD_MCEP.htm.

9 The Global Partnership for Safe and Sustainable Agriculture has produced a coffee standard and is now working on standards for fruits and vegetables, flowers and ornamentals, and aquaculture, available at http://www.eurep.org/Languages/English/index_html.

10 See Kingsbury, Krisch, and Stewart, 'The Emergence of Global Administrative Law', 68 Law and Contemporary Problems (2005) 15. See also the Working Papers of the Global Administrative Law Project of the Institute for International Law and Justice, New York University School of Law, available at www.iilj.org. For an early effort to map the influence of emerging global issues and discourses on domestic administrative law, see A.C. Aman, Jr., Administrative Law in a Global Era (1992), at 131-156. 
tropical countries as a grave and gathering disaster. Although the causes of tropical deforestation are multiple (including population growth, conversion of forests to farming and other uses, infrastructure expansion, and fire ${ }^{11}$ ) and vary from case to case, an important cause in many cases is consumption of tropical timber in developed countries. The responsibility of Northern consumers combined with the importance of Northern currency to developing countries prompted calls by some environmental groups for a consumer boycott of tropical timber. ${ }^{12}$ Before long, however, this strategy was rejected as counter-productive, since it was seen as discriminatory by developing countries and since the loss of Western revenues for developing country forest products could lead to accelerated forest conversion and destruction. ${ }^{13}$

Replacing the tropical timber boycott were calls for a system by which timber from sustainably managed forests could be certified and labelled as such, enabling consumers to identify it in the marketplace. By purchasing only wood certified through such a system, Northern consumers could avoid contributing to destructive forestry and, better yet, reward good forestry. The original proposals called for a certification system operated, or at least developed, by the International Tropical Timber Organization (ITTO), ${ }^{14}$ an intergovernmental organization of tropical timber producing and consuming countries established in 1986 under the auspices of the United Nations. ${ }^{15}$ The ITTO resisted and eventually rejected those proposals, to the great consternation of many environmental activists at the time. ${ }^{16}$

Other efforts to effectuate tropical forest protection also foundered, the most significant being the failed push for a binding forest convention at the 1992 United Nations Conference on Environment and Development (UNCED) in Rio. But UNCED performed the important function of strongly and broadly crystallizing the global discourse of 'sustainable development', which had been under development for the past two decades. The concept of sustainable development that emerged conceives economic development, environmental protection and social justice as inextricably interlinked and mutually necessary. Most governments, North and South, have embraced this concept, as have most social and environmental NGOs and business organizations. Today it provides the organizing framework for virtually every transnational discussion of environmental policy. In the intergovernmental arena there has been much work aimed at defining sustainable development and agreeing on

11 Brown, 'Cut and Run? Evolving Institutions for Global Forest Governance', 13 J Int'l Developments (2001) 852 .

12 A. Kolk, Forests in International Environmental Politics: International Organisations, NGOs and the Brazilian Amazon (1996). Particularly important were Friends of the Earth in the UK and the Rainforest Action Network in the US: Bartley, 'Certifying Forests and Factories: States, Social Movements, and the Rise of Private Regulation in the Apparel and Forest Products Fields', 31 Politics \& Society (2003) 433. These organizations were also important players in the subsequent movement for forest certification.

13 Ibid

14 C. Elliott, Forest Certification: A Policy Perspective (2000), at 5.

15 F. Gale, The Tropical Timber Trade Regime (1988).

16 Elliott, supra note 14; Gale, supra note 15. 
indicators of its achievement. But these inter-governmental efforts have had little apparent impact on either state regulatory practices or tropical forest degradation. ${ }^{17}$

In the extra-governmental arena, a small group of environmental NGOs, timber producers and wood processors sought to institutionalize sustainable development in the form of a non-governmental forest certification system. In 1989 the Rainforest Alliance, a US-based environmental NGO, created a free-standing forest certification programme called SmartWood, which certified several timber operations as sustainably managed and authorized their products to carry its logo. ${ }^{18}$ In the fall of 1993 a larger group led by the World Wildlife Fund, and including several other NGOs, smallscale timber producers, high-end furniture makers, retailers (most notably the British do-it-yourself company, B\&Q), and individual forestry professionals, founded the Forest Stewardship Council (FSC). The FSC was conceived from the outset as a global programme for forest certification. Its primary functions would be to set standards for certification and to accredit certification organizations like SmartWood. ${ }^{19}$ Products certified under the FSC system would be entitled to carry the FSC logo. ${ }^{20}$

The FSC was constituted as a multi-stakeholder policy-making body with the mission of promoting 'environmentally responsible, socially beneficial and economically viable management of the world's forests, by establishing a worldwide standard of recognized and respected Principles of Forest Management'. ${ }^{21}$ Its founders drew on several important currents of thought. The most obvious was the sustainable development-sustainable forest management (SFM) discussion, which was incorporated directly into the organization's guiding principles as described below. A related current was the concept of multi-stakeholder decision-making, as had recently been incorporated in the US Negotiated Rulemaking Act of $1990^{22}$ among many other state administrative policies. The third was the more obscure lore of trans-governmental standard setting. ${ }^{23}$ At the FSC's founding, the International Organization for Standardization (ISO) had been in

17 Gulbrandsen, supra note 2, at 80-81.

\section{SMARTWOOI}

smartwood-seal.gif.

19 For more detailed histories, see Elliott, supra note 14; Meidinger, 'Human Rights, "Private” Environmental Regulation, and Community', 6 Buffalo Environmental LJ (1999) 123, and B. Cashore, G. Auld, and D. Newsom, Governing Through Markets: Forest Certification and the Emergence of Non-State Authority (2004).

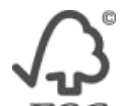

20 FSC , available at http://www.fsc.org/gr/en/home_header/logo.gif.

21 Forest Stewardship Council Principles and Criteria for Forest Management, available at http:// www.fsc.org/keepout/en/content_areas/77/71/files/FSC_STD_01_001_FSC_Principles_and_Criteria_ for_Forest_Stewardship_2004_04.PDF.

22101 PL 648; 104 Stat 4969 (1990).

23 See, generally, Hamilton, 'The Role of Nongovernmental Standards in the Development of Mandatory Federal Standards Affecting Safety or Health', 56 Texas L Rev (1978) 1329; R.E. Cheit, Setting Safety Standards: Regulation in the Public and Private Sectors (1990); H. Schepel, The Constitution of Private Governance: Product Standards in the Regulation of Integrating Markets (2005). 
operation for over four decades, and had developed a large body of knowledge on 'technical standard setting' - defining, for instance, the required attributes of a $6 \mathrm{~mm}$ screw or of the magnetic strip on a credit card. ${ }^{24}$ But the ISO had also recently ventured into setting standards for organizational management systems with its ISO 9000 series of standards. ${ }^{25}$ Following the Rio Conference it had also begun work on an Environmental Management Standard that would eventually become the ISO 14000 series. ${ }^{26}$ Although the standard ultimately focused almost entirely on organizational procedures for analysis and management, it was nonetheless an important development by virtue of focusing on corporate management capacity and accountability for performance. Additionally, some of the FSC's founders had been involved with self-consciously progressive trans-governmental standard-setting efforts, most importantly in organic agriculture, where the International Federation of Organic Agriculture Movements (IFOAM) provided a fund of experience. ${ }^{27}$ Finally, the rise and consolidation of an international trade regime structured by World Trade Organization (WTO) rules and related national rules provided a surrounding frame within which the FSC's institutions were designed. While it was intended to counter the ill effects of the rapidly expanding global timber market, the FSC also only makes sense in the context of a well-functioning international trading system. It depends on the use of market signals to institute incentives for environmental and social protection. It is thus part of a whole family of 'regulatory reform' initiatives relying on markets, information and flexibility that have emerged over the past three decades. ${ }^{28}$ Although there remains some tension between the assumptions of the certification movement and those of the international trading system, certification programmes have been careful to avoid conflicts with international trade rules and have often made adjustments to accommodate them. The legal status of forest certification programmes under WTO rules remains subject to some doubt, however, and is still to be worked out in the future. ${ }^{29}$

In sum, the FSC programme was built out of an amalgam of sustainable development discourse, participatory, multi-stakeholder policy-making processes, technical standard-setting conventions, and emerging international trade rules. These were

24 See generally Meidinger, supra note 19.

25 See generally, Roht-Arriaza, 'Private Voluntary Standard-Setting, the International Organization for Standardization, and International Environmental Lawmaking', in G. Handl (ed.), 6 Yearbook of Int'l Envt'l L (1995), at 107, 119. Essentially, the ISO 9000 standards sought to create standards for good business management, or, as it was often called at the time, 'total quality management'.

26 See generally, T. Tibor and I. Feldman, ISO 14000: A Guide to the New Environmental Management Stand$\operatorname{ards}$ (1995).

27 International Federation of Organic Agriculture Movements, available at http://www.ifoam.org; Courville, 'Standards and Certification', in P. Kristiansen and A. Taji (eds), Organic Agriculture: A Global Perspective (forthcoming); Personal Interviews.

28 Meidinger, 'Forest Certification as Environmental Law Making by Global Civil Society', in Meidinger, Elliott, and Oesten, supra note 4, at 293, 304-308.

29 See Bernstein and Cashore, 'Non-state Global Governance: Is Forest Certification a Legitimate Alternative to a Global Forest Convention?', in J.J. Kirton and M.J. Trebilcock (eds), Hard Choices, Soft Law: Voluntary Standards in Global Trade, Environment and Social Governance (2004). 
also perforce central concerns of the competitor certification programmes that soon arose in response to the FSC.

\section{B Primary Actors}

\section{Forest Certification Programmes}

The FSC is the driving force in forest certification, having challenged the forestry establishment with an ambitious structure and agenda since its inception. The FSC's international governing body, the General Assembly, is constituted of three chambers economic, social and environmental - with equal voting power. ${ }^{30}$ These chambers are further divided into Northern (developed country) and Southern (developing country) sub-chambers, each also holding equal decisional power, thereby counterbalancing the comparative over-representation of members from Northern countries and addressing critiques that post-Rio sustainable development initiatives have been dominated by Northern interests. While the General Assembly holds ultimate authority in the FSC system, the organizational bylaws and statutes in fact delegate a great deal of decisional authority to the nine-member Board of Directors, which traditionally acts in close consultation with the Executive Director. Membership in the FSC is open to all organizations and individuals who subscribe to the FSC's principles and whose applications are endorsed by two existing members. Governments were originally barred from membership, but in 2002 the General Assembly revised that policy to allow representatives of government owned or controlled forest management organizations to be members of the economic chamber. ${ }^{31}$ Certification bodies are also permitted to be members of the Economic Chamber and a number of them participate quite avidly. The 2005 General Assembly considered a proposal by a respected international staff member to bar employees of the FSC from being members, but rejected it. ${ }^{32}$ Thus, FSC

30 Forest Stewardship Council AC Bylaws, available at http://www.fsc.org/keepout/en/content_areas/77/ 84/files/FSC_By_laws_revised_November_2002.PDF. Members for the most part choose the chambers of which they are members, although profit-making organizations are expected to join the economic chamber. The idea that participation by environmental, economic, and social interests is key to good forest policy had been adopted in non-binding form for governments in the Rio Forest Principles: United Nations, 'Non-legally Binding Authoritative Statement of Principles for a Global Consensus on the Management, Conservation and Sustainable Development of All Types of Forests', A/Conf.151/26, Principle 2d, available at http://www.un.org/documents/ga/conf151/aconf15126-3annex3.htm. It is interesting to note that in the early years after the FSC was founded the economic chamber was denied structural parity with the environmental and social chambers. Only after several years was it given equal voting power. Even today the economic chamber is limited to two of the nine members of the Board of Directors.

31 Statutory Motion 2 to Allow Participation of Public Owned Companies. Final Motions and Results from the FSC General Assembly 2002, available at http://www.fsc.org/keepout/en/content_areas/77/75/ files/FSC_General_Assembly_2002_Final_Motions.pdf. The bylaws also provide for independence from governments as well as commercial organizations, although they permit acceptance of funding from and collaboration with governments: supra note 29 , para. 8 .

32 FSC 2005 General Assembly Statutory Motion 2. The sponsor's primary rationale was that a staff member who was also a member of a specific chamber could not avoid the appearance of partiality when responsible for carrying out the policies settled upon in the General Assembly. This view carried some weight with many participants, but ultimately gave way to a pragmatic sense that these problems could be handled in practice without barring staff members from membership and losing the value of their 
membership remains quite open and may be growing more so. At present the FSC has approximately 600 members, two-thirds being organizations and one-third individuals. ${ }^{33}$

The FSC champions a broad and demanding set of standards for certification. Formally denominated 'principles and criteria' and described in more detail below, they require conformance to applicable laws and treaties, possession of clear property rights and a management plan, as well as protection of indigenous rights, workers, local communities, biological diversity, and areas of high conservation value, among other things. ${ }^{34}$ All of these are in turn put into practice through more detailed indicators in national and regional standards, developed by local working groups with the goal of tailoring the global principles and criteria to specific environments. ${ }^{35}$

The founding of the FSC met with considerable scepticism and hostility from most traditional forestry interests. In North America, large forestry companies soon took steps to establish their own certification programmes. This was not as difficult as one might expect, because many large forest products corporations were familiar with the ISO programmes and were casting about for ways to improve their generally poor public images. ${ }^{36}$ Thus, the highly export-dependent Canadian forest industry collaborated with the Canadian ISO affiliate, the Canadian Standards Association (CSA), to develop a forestry-specific, ISO-based standard. ${ }^{37}$ In the United States, the American Forest and Paper Association, comprising approximately 200 of the largest companies in the industry, began to develop its own free-standing standard. The resulting Sustainable Forestry Initiative (SFI) started out as a vague corporate code of conduct created by staffers using focus groups to determine the minimum commitments necessary to allay public distrust. ${ }^{38}$ Initially it did not even provide for the possibility of third-party certification, but in 1998 it began to encourage, although not require, the practice. ${ }^{39}$

experience for open deliberations. One reading of this decision is that the FSC's concept of how to have an adaptive governance structure includes allowing the broadest possible legislative participation.

33 See http://www.fsc.org/keepout/en/content_areas/77/82/files/5_2_2_FSC_Membership_List_2005_ 03_16.pdf. Individuals are limited to $10 \%$ of the total voting power in each sub-chamber, thus giving effective control to organizational members: Bylaws, supra note 24, para. 13.

34 FSC Principles and Criteria of Forest Stewardship, available at http://www.fsc.org/en/about/policy_ standards/princ_criteria. The tendency to enunciate and attempt to propagate core principles seems to typify not only the sustainable development and international human rights domains, but also more technical areas of international regulation, such as banking and securities: see, e.g., Zaring, 'Informal Procedure, Hard and Soft, in International Administration', 5 Chicago J Int'l L (2005) 547, at 580.

35 National and regional standards are developed by National Initiatives, which are supposed to be structured so as broadly to reflect important interests in the relevant locale. In some particularly large countries, such as the US and Canada, specific standards are developed for individual regions. For a current list of National Initiatives, see http://www.fsc.org/keepout/en/content_areas/77/77/files/5_1_2_2005_ 10_20_FSC_National_Initiatives.pdf.

36 Nash, 'Industry Codes of Practice: Emergence and Evolution', in T. Dietz and P.C. Stern (eds), New Tools for Environmental Protection: Education, Information, and Voluntary Measures (2002), at 235, 237-238.

37 Canadian Standards Association Standard for Forest Management, available at http://www.sfms.com/ csa.htm.

38 See Meidinger, supra note 19 , for an early history.

39 See generally Cashore, Auld, and Newsom, 'The United States' Race to Certify Sustainable Forestry: Non-State Environmental Governance and the Competition for Policy-Making Authority', 5 Business and Politics (2003) 219. 
The SFI has since gone through numerous other iterations, gradually getting stronger and more detailed, and eventually being placed under the control of a nominally independent multi-stakeholder board. ${ }^{40}$

Several tropical countries have also developed their own certification programmes. Indonesia, for example, has the Lembaga Ekolabel Indonesia (LEI - Indonesia Ecolabel Institute) programme. ${ }^{41}$ It is the result of a complex negotiation among traditional forestry powers (primarily the powerful government ministries responsible for allocating timber concessions on state-owned forests and large timber-producing corporate concessionaires) and emerging Indonesian and established transnational NGOs. In part to counter ongoing enforcement and credibility problems, LEI has forged a tenuous but continuing alliance with the FSC. Currently, products certified under either programme must meet the requirements of both. ${ }^{42}$

Finally, in the late 1990s traditional European forestry interests entered the tournament of certification programmes. A few European forestry companies, particularly in Scandinavia, had engaged in the FSC system from the outset, but most remained outside it. Many European forestry interests initially supported the idea of certifying tropical timber, because they felt unfairly disadvantaged by its lower environmental and labour standards. When it became clear that requiring certification only of tropical timber would violate international trade rules, ${ }^{43}$ however, and when environmental groups began agitating for certification of European timber, they reacted angrily. This was due to both the traditional high regard in which the European industry held itself and the small size of many European forest owners, making it difficult for them to find the economies of scale to readily finance and achieve FSC certification. ${ }^{44}$

After initially resisting certification, European forest owners gradually came to accept it as inevitable and then decided to establish their own programme. The resultant Pan-European Forest Certification Council (PEFC) was formed during 1998 and 1999. It drew upon the by then substantial lore of forest certification and sustainable forest management to form a system with many similarities to, but also important differences from, the FSC. The first difference was that the PEFC portrayed itself not as promulgating a single overall standard to be adapted to variable local conditions, but rather as providing a common framework for the mutual recognition of nationally based certification programmes that had adopted their own legitimate rules of sustainable forestry, as well as an appropriate set of certification institutions to implement them. Second, although formed as a multi-stakeholder structure nominally independent of governments, the PEFC is controlled largely by traditional forestry interests, primarily landowners and European forest products corporations. These

\footnotetext{
40 Meidinger, Elliott, and Oesten, 'The Fundamentals of Forest Certification', in Meidinger, Elliott, and Oesten, supra note 4 , at $12-14$.

41 Ibid.

42 Ibid.

43 Austria adopted such a statute in 1992 and shortly thereafter repealed it in the face of criticism from developing countries and pressure from Austrian industrialists who feared a trade war: D. Humphries, Forest Politics: The Evolution of International Cooperation (1996), at 73.

44 Meidinger, Oesten, and Elliott, supra note 40, at 17-18.
} 
interests also have longstanding relationships with and influence on European government forestry ministries, and the PEFC has brought government agencies into more direct interactions with forest certification. The PEFC grew quickly and now includes approximately 18 endorsed national programmes with another dozen in process. ${ }^{45}$ In late 2003 the PEFC rechristened itself the Programme for the Endorsement of Forest Certification, thereby opening membership to non-European programmes and laying claim to global reach. ${ }^{46}$

Overall, although the actual number of forest certification programmes and their relationships to each other remain subject to a surprising amount of uncertainty, it is clear that they are organized in two basic alliances. The first is the FSC system, which is most closely identified with transnational environmental NGOs but also has substantial numbers of business and social justice members. The second is the PEFC alliance, which is most closely identified with landowners and industry, but has increasingly sought to bring in other interests. As noted above, these alliances constantly monitor and adjust to each other. They show a considerable amount of institutional mimicry, but also promote procedures and standards that differ in various ways, many of which are described below. They compete not only for certification clients, but also for approval and legitimacy in various arenas, including the forestry sector, government policy and public opinion.

\section{Other Certification-oriented Organizations}

Both the FSC and the PEFC alliances maintain relationships with various other certification-oriented organizations, some of which operate certification programmes in other sectors and others of which play umbrella roles. The FSC is part of the International Social and Environmental Accrediting and Labelling Alliance (ISEAL), a recently founded association of eight organizations involved in progressive standard setting, certification, and labelling programmes. ${ }^{47}$ ISEAL's purposes include improving the standard-setting processes of its members and strengthening the governance and legitimacy of their programmes. ${ }^{48}$ ISEAL's strategy has been to accommodate and apply ISO processes, rather than to challenge them. The FSC also increasingly refers to and seeks to comply with ISO standard-setting and certification protocols. An important sister organization to the ISO, the International Accreditation Forum (IAF), is an international association of nationally-based accreditation bodies among whose goals is to create a single international programme of conformity assessment for its members. Although ISEAL and some of its organizations were

45 PEFC Members and Schemes, available at http://www.pefc.org/internet/html/members_schemes/ 4_1120_59.htm.

46 Endorsed non-European programmes currently exist in Australia, Brazil, Canada (the CSA programme), and Chile. Countries with programmes likely to receive future endorsement include Gabon, Malaysia, Russia, and the US SFI programme: ibid.

47 Current members include the Fairtrade Labelling Organizations, the Forest Stewardship Council, the International Federation of Organic Agriculture Movements, the International Organic Accreditation Service, the Marine Aquarium Council, the Marine Stewardship Council, the Rainforest Alliance, and Social Accountability International. See http://www.isealalliance.org/membership/founding.htm.

48 ISEAL Alliance, available at http://www.isealalliance.org/about/index.htm. 
earlier denied membership in the IAF (reportedly on grounds that they are international, rather than national organizations), the PEFC recently gained associate membership. This could turn out to be important because the European Union treats IAF membership as a condition of competency to carry out accreditation in the EU. ${ }^{49}$ Even more recently, however, the FSC attained membership in the World Standards Services Network (WSSN), which includes international standard-setting organizations such as the ISO itself, as well as the International Electrotechnical Commission and the International Telecommunication Union. ${ }^{50}$ WSSN members appear to enjoy considerable deference in WTO analyses of technical barriers to trade, although the exact nature of any such deference remains unclear.

\section{Related Interest Groups}

The importance of various business and environmental groups has already been mentioned. Their roles in the overall system are complex and shifting. Some corporations, for example, participate in both the FSC and the PEFC alliances. The same is true of some environmental organizations. The Nature Conservancy, for example, currently has representatives on the boards of both the FSC-US and SFI. It is also important to note that charitable foundations have been key supporters of the FSC programme. ${ }^{51}$ More distant from the official operations of the certification programmes, but still important, have been a number of social movement actors. Already mentioned was the tropical timber boycott brought by Northern environmental groups. In addition, many large forest products corporations have been subject to various demonstrations, lawsuits, shareholder resolutions, media campaigns, national regulatory initiatives, and the like, which they typically see as posing risks that should be controlled. ${ }^{52}$

Among the most important actors in this arena have been the 'forest campaigners' who pressure large forest products organizations to embrace certification. In one mode they have carried out large public media campaigns. Perhaps the most important of these was the campaign of the Rainforest Action Network (RAN - not to be confused with the Rainforest Alliance) to persuade Home Depot Corporation, the world's largest home-improvement retailer, ${ }^{53}$ to embrace FSC certification. RAN held a series of well dramatized and publicized demonstrations at Home Depot stores in North America, seeking to associate the company's brand with environmental destruction. After more than two years and approximately 600 such actions, ${ }^{54}$ Home

49 Humphreys, 'The Certification Wars: Forest Certification Schemes as Sites for Trade-Environment Conflicts', paper presented to the 'Privatizing Environmental Governance' Panel, 46th annual convention of the International Studies Association, Honolulu, Hawaii, 1-5 Mar. 2005.

50 World Standards Services Network, available at http://www.wssn.net/WSSN/aboutwssn.html.

51 Among the most important have been the Ford, Macarthur, and Rockefeller Brothers. See generally Elliott, supra note 14.

52 For a general discussion of the brand manipulation involved, see Haufler, 'New Forms of Governance: Certification Regimes as Social Regulations of the Global Market', in Meidinger, Elliott, and Oesten, supra note 40 , at $237-247$.

53 Home Depot Announces Record Fourth Quarter and Fiscal Year 2004 Results, available at http:// ir.homedepot.com/ReleaseDetail.cfm?ReleaseID $=156400$.

54 Personal interviews. 
Depot agreed to promote FSC certification and to buy all of the FSC-certified products it can find. ${ }^{55}$ Folklore has it that when RAN turned its attention to the second largest US wood-products retailer, Lowes, only two phone calls and one meeting were necessary to achieve a similar result. ${ }^{56}$ RAN has since carried out similar actions against a multitude of major corporations. It celebrated an important victory in 2003, when Boise Cascade, a major timber and forest products producer, agreed to stop selling wood from 'endangered forests, ${ }^{57}$ and currently has its sights on Weyerhaeuser, a major transnational forest products company, ${ }^{58}$ as well as a number of companies in the finance sector. ${ }^{59}$

Forest campaigners also carry out more covert operations. These typically involve visiting sites of tropical forest destruction and tracking the illegally logged timber to retailers in developed countries. Once the forest campaigners have documented the trail from devastated forest to Northern retailer (typically with photos and video cameras, and sometimes with invoices obtained through dumpster diving) they contact or visit the retailer's corporate offices and threaten to publicize its complicity in the destructive practices. Reportedly, such visits have led a number of corporations to cease destructive practices, and sometimes to embrace certified products. ${ }^{60}$

\section{Global Networks}

Although global networks are ordinarily viewed as conduits rather than sources of action, they play a more affirmative role in forest certification. The actors described above depend heavily on preexisting global networks - most importantly transnational business networks and product chains. ${ }^{61}$ These networks can be understood as actors because they have built-in expectations and momentum. The commitments of trade networks to profits and economic protection of their members are dynamic directions that can activate them in favour of certification. And once a major network actor such as Home Depot is committed to certification, it can activate other network members in the same direction.

55 Carlton, 'Against the Grain: How a Tiny Council Cut Logging Abuse', Wall Street Journal, 26 Sept. 2000, at $\mathrm{A} 12$.

56 This has been mentioned as fact by several interviewees, although documentation has not turned up. Similar campaigns have been carried out in other countries. For example, Greenpeace Germany ran a successful campaign to persuade the wood processing company, Rettenmeier, including some of its suppliers in the Archangelsk region of Russia, to obtain FSC certification.

57 Boise Cascade Timber and Fiber Procurement Policy, available at http://www.bc.com/environment/ policyProcure.jsp. See also Rainforest Action Network, '19 Years of Impact: Annual Report for 2003', available at http://www.ran.org/about_ran/ran_annual_2003.pdf. See generally, Sasser, 'The Certification Solution: NGO Promotion of Private, Voluntary Self-Regulation', paper presented at the 74th Annual Meeting of the Canadian Political Science Association, 29-31 May 2002, at Toronto, Ontario. See http://www.ran.org/ran_campaigns/old_growth/.

59 Goldman Sachs recently announced a major greenward shift in its investment policies: Goldman Sachs Environmental Policy Framework, available at http://www.gs.com/our_firm/our_culture/ social_responsibility/environmental_policy_framework/docs/EnvironmentalPolicyFramework.pdf.

60 Personal interviews.

61 Sasser, 'Gaining Leverage: NGO Influence on Certification Institutions in the Forest Products Sector', in L. Teeter, B. Cashore, and D. Zhang (eds), Forest Policy for Private Forestry (2002). 


\section{Governments}

Governments are often portrayed as non-actors in forest certification, and indeed their inability to act in concert to establish binding international forestry policies combined with their increasing convergence on trade polices created important preconditions for the rise of forest certification. ${ }^{62}$ In fact, however, governments are involved in certification in a variety of ways. First, the threat of increased governmental regulation in the absence of effective non-governmental regulation has sometimes been a background factor in the acceptance of certification. Second, certification programmes have generally sought to garner a certain amount of government and public support by promoting conformance to existing government laws. Thus, certification programmes implicitly claim states as their allies by mandating compliance with state laws. Third, many of the certification programmes draw directly on government resources, such as criteria and indicators produced by intergovernmental organizations and conferences, and the non-FSC ones in particular can involve fairly direct interactions with governments. Thus, the PEFC, CSA, and LEI involved much government influence, albeit with limited roles for government officials in formal certification processes. Even in the FSC system, it is now possible for representatives of government owned or controlled companies to be members of the international economic chamber, and some national working groups involve government participants.

Recently, governments have become more directly involved in certification. Most strikingly, a number of government agencies have chosen to obtain certification of state owned and managed forests. ${ }^{63}$ While these actions sometimes reflect a desire to retain or obtain market access, agencies sometimes also seem to think that their broader political credibility or legitimacy may be enhanced by certification. Second, a growing number of governments, particularly in Europe, have adopted certified forest products procurement programmes, thus helping to create markets for certified products and lending further legitimacy to certification requirements. ${ }^{64}$ Third, several governments either make certification a requirement for producing commercial timber in their jurisdictions or treat certification as de facto compliance with applicable laws. ${ }^{65}$ Certification standard-setting processes also appear to have had considerable influence on the legal requirements of some governments. ${ }^{66}$ Finally, many governments

62 See, e.g., Bartley, 'Institutional Emergence in an Era of Globalization: The Rise of Social and Environmental Certification Systems', Working Paper, Dept. of Sociology, Indiana University (2005).

63 E.g., Paschalis, 'Forest Certification in Poland', in B. Cashore, F. Gale, E. Meidinger, and D. Newsom (eds), Confronting Sustainability: Forest Certification in Developing and Transitioning Countries (forthcoming); Actins and Kore, 'Forest Certification in Latvia', in ibid. Many other national and provincial land management agencies have also chosen to have their lands certified, although no comprehensive summary appears to exist.

64 See generally, FERN, 'To Buy or Not to Buy: Timber Procurement Policies in the EU', Jan. 2004, available at http://www.fern.org/pubs/reports/procure.pdf; Sprang et al., 'Public Procurement and Forest Certification: Assessing the Implications for Policy, Law and International Trade', Report to the European Commission (forthcoming).

65 See, e.g., the case studies of Bolivia, Guatemala, Latvia, and Poland in Cashore et al., supra note 63.

66 Ibid. 
have become actively involved in an alliance with certification organizations, environmental NGOs, and some transnational corporations in efforts to combat 'illegal logging'. ${ }^{67}$

\section{Summary}

Forest certification in particular, and transnational forestry regulation in general, is worked out through complex interactions among a multitude of governmental and non-governmental actors in multiple fora. It can therefore be understood neither as a form of industry 'self-regulation', nor as a form of governmental or intergovernmental regulation. Rather, it is increasingly taking the form of a transnational, rule-oriented system made up of competing, mutually adjusting organizations and institutions. ${ }^{68}$ Important negotiations take place with regard to several types of issues. The next section describes the primary institutional arrangements adopted by certification programmes, some of which are coming to be taken for granted and others of which remain very much contested.

\section{Institutional Building Blocks}

Each of the forest certification programmes outlined above draws upon and necessarily interacts with a received body of certification experience. Trans-governmental standard-setting systems have evolved four common institutional components. Most obviously, a certification system needs procedures for setting the standards to which enterprises are certified, and then for certifying that specific firms meet those standards. These are analogous to rule-making and adjudication (or licensing ${ }^{69}$ procedures in administrative law. In addition, most systems have developed methods for accrediting certifiers. These are often quite important, since a certification process must be accepted as credible if a certification programme is to be effective, and that credibility may depend heavily on the credibility of the person carrying out the review. Finally and more recently, a number of certification programmes have developed requirements for labelling specific products as deriving from certified operations. These are particularly important where there is a considerable distance between the production process and consumption. The following sections first discuss forest certification in terms of their rule-making, adjudication and enforcement mechanisms, and then characterize them in terms of some of the broader criteria of administrative law, including stakeholder participation, deliberation, transparency, expertise and accountability.

67 Tacconi, Boscolo, and Brack, 'National and International Policies to Control Illegal Forest Activities', Center for International Forestry Research (2003), available at http://www.cifor.cgiar.org/publications/ pdf_files/events/Illegal-logging.pdf.

68 By 'institutions' I mean standardized sets of practices, norms, and relationships for performing and stabilizing social function: see, e.g., 13, R. Scott, Institutions and Organizations (1995).

69 Licensing (or permitting) is classified as a form of adjudication in US administrative law. 


\section{Rule-making}

Administrative rule-making is ordinarily structured by both substantive and procedural requirements, as well as by customary practices and modalities of various kinds. The same is true of forest certification.

\section{A Substance}

Substantive requirements in government-based administrative systems are typically portrayed as deriving largely from statutes. But the statutes of state legal systems can provide only limited guidance for global certification systems, since they vary by country and are perhaps implied to be inadequate by the very existence of certification programmes. Yet there exists a transnational discourse on sustainable forest management (SFM), which provides much of the substantive framework for certification programmes. When the FSC was founded, the concept of sustainable forestry had long been the guiding credo of forestry. ${ }^{70}$ As a focal concept, it had undergone a longterm debate and development, much of which had been incorporated in the norms and sometimes the laws of forestry. In essence that development had gradually expanded the criteria which forest managers must take into account from (1) ensuring a steady flow of timber ${ }^{71}$ to (2) protecting the range of forest ecological functions, components and services to (3) protecting the many societal interests tied to the forest (although not always in this order). Much of this expansion occurred in tandem with the emergence of 'sustainable development' discourse in the broader fields of environmental regulation and economic development. ${ }^{72}$ These criteria are often in some conflict with each other, since preserving ecological functions may not be the best way to maximize timber yields, and since preserving societal interests may also be at odds with timber production or ecological preservation. ${ }^{73}$ Moreover, which ecological and social interests should be protected, and how, are contested questions in most societies.

The FSC took a fairly aggressive, socially and environmentally protective stance in promulgating its guiding Principles and Criteria. As noted above, they include requirements for the protection of indigenous peoples, workers, communities and the environment. It seems clear that many of these concepts were adopted from and coordinated with the human rights and sustainable development movements in

70 But note that the FSC does not make any claim that certified forestry is in fact sustainable, first because some of its own members object that no one can know for sure until many years after the certification occurs, and secondly because ISO policies caution against use of the label.

71 For an illuminating review of the scientific elaboration of the sustained yield criterion, see Lowood, "The Calculating Forester: Quantification, Cameral Science, and the Emergence of Scientific Forestry Management in Germany', in R. Frängsmyr, J.L. Heilbron, and R.E. Rider (eds), The Quantifying Spirit in the 18th Century (1990).

72 E.g., D. Humphreys, Forest Politics: The Evolution of International Cooperation (1996), at 66-69. On the development of the concept of sustainable development in international environmental law see P. Sands, Principles of International Environmental Law (2nd edn., 2003), at 252-266.

73 Schanz, 'Sustainable Forest Management', in J. Burley, J. Evans, and J. Youngquist (eds), Encyclopedia of Forest Sciences (2004), 1345-1350; Romm, Sustainable Forestry: An Adaptive Social Process', in G.H. Aplet et al. (eds), Defining Sustainable Forestry (1993), at 280-293. 
international affairs. The FSC was thus seeking to impose standards in forestry that incorporate concerns well beyond the common purview of profit-maximizing corporations. While this is similar to many state-based regulatory programmes, which seek to curb selected negative externalities of economic activity, the FSC programme is unusually ambitious in that it seeks to combine economic, environmental and social regulation. These concerns would typically be divided among several state agencies, if indeed they were addressed at all in national forest policy.

The rigorous requirements of the FSC programme played an important role in provoking the industry response that ultimately led to the PEFC alliance of programmes. First out of the box was the American Forest \& Paper Association (AF\&PA), which produced a remarkably weak standard, but made it a requirement of continued membership in the Association. The SFI principles simply required member firms to commit to practising and promoting sustainable forestry, improving long-term forest health and productivity, managing lands 'of special significance' in appropriate ways, and continuously improving their practices of forest management. ${ }^{74}$ Those principles were given somewhat more detail in a series of objectives and performance measures, but were still extremely loose and subject to interpretation. The original SFI standard contained no requirements regarding workers, indigenous peoples or local communities. ${ }^{75}$

The Canadian Standards Association also produced a standard in the same time period, arguably somewhat more demanding than the AF\&PA's in that it required more stakeholder participation, but also considerably more friendly to industry than was the FSC standard. ${ }^{76}$ The PEFC and its member programmes also produced more industry-friendly standards, but accepted the legitimacy of including labour and human rights concerns by adopting a definition of SFM originally developed by the intergovernmental Helsinki Ministerial Conference on the Protection of Forests in Europe in 1993:

the stewardship and use of forest lands in a way and at a rate, that maintains their biodiversity, productivity, regeneration capacity, vitality and their potential to fulfill now and in the future, relevant ecological, economic, and social functions, at local, national, and global levels, and that does not cause damage to other ecosystems. ${ }^{77}$

Of course, the above definition, while affirming environmental, economic and social responsibilities of forest managers, leaves much room for debate about their

74 Meidinger, supra note 19, at 206-207. As noted below, 'continuous improvement' is a hallmark of ISOstyle certification programmes.

75 The SFI's explanation at the time was that these were matters of other policies and of state and federal law.

76 The CSA eventually offered a substantive standard based on criteria and indicators developed by the Canadian Council of Forest Ministers in tandem with the Helsinki and Montreal processes. Firms could adopt this substantive standard if they wanted to, but could also opt to develop their own: see http:// www.csa-international.org/product_areas/forest_products_marking/program_documents/Z809-02_revised_ 1030.pdf.

77 PEFC, available at http://www.pefc.org/internet/resources/5_1177_286_file.1038.pdf; MCPFE, Resolution H1, Preamble, para. D (1993), available at http://www.mcpfe.org/resolutions/helsinki/resolution_h1.pdf. 
substance. And indeed very intensive debate has occurred both within and among certification programmes. The major issues have included the following:

- limits on clear felling

- duties to protect old growth forests

- duties to protect endangered species and habitats

- the relationship between natural forests and plantations

- limits on use of chemicals and genetically modified organisms

- limits on the introduction of non-native species

- duties to workers

- duties to local communities

- duties to indigenous peoples

It is neither possible nor important to detail the evolution of the debate and standards in this paper. Broadly speaking, while there are still considerable and important differences between the industry-oriented programmes and the FSC, there has been a significant convergence, more in the direction of the FSC standards than vice versa. ${ }^{78}$ Forest certification rule-making processes have thus been a central domain for both contesting and defining the meaning of sustainable forest management. At a relatively high level of abstraction the concept now seems to embody several key principles, some explicit and others implicit. First, forestry enterprises have duties to protect both environmental functions and dependent social groups, such as indigenous peoples, local communities and workers. As will become more apparent below, these are defined in terms of both substantive and procedural elements. One important emerging tendency is that forestry firms seeking certification are beginning to take responsibility for fostering local civic and democratic institutions in developing and transitioning societies. ${ }^{79}$ Second, a defining, if often unstated and unchallengeable, purpose of forestry and forest certification is to support effective and functional global markets. Such markets require local institutions capable of stabilizing forestry and protecting property rights. Forest certification programmes therefore must mesh with and promote effective local and national social control institutions.

78 Cashore, Auld, and Newsom, supra note 39; Meridian Institute, Comparative Analysis of the Forest Stewardship Council and Sustainable Forestry Initiative Certification Programs (2001); Humphries, 'The Certification Wars: Forest Certification Schemes as Sites for Trade-Environment Conflicts', paper presented to the Privatizing Environmental Governance Panel, 46th annual convention of the International Studies Association, Honolulu, Hawaii, 1-5 Mar. 2005; Overdevest, 'Treadmill Politics, Information Politics, and Public Policy: Toward a Political Economy of Information', 18 Organization and Environment (2005) 72; McDermott, Noah, and Cashore, 'Differences That "Matter"? Identifying Analytical Challenges in the Comparison of Forest Certification Standards', Working Paper, Yale Program on Forest Certification, available at www.yale.edu/forestcertification/pdfs/McDNoahCash120205.pdf.

79 Tysiachniouk and Meidinger, 'Using Forest Certification to Strengthen Rural Communities: Cases from Northwest Russia', Paper prepared for the ASA Mini-Conference on 'Community and Ecology: The Intersection of Community Sociology and Environmental Sociology', 12-13 Aug. 2004, San Francisco, under journal review, available at www.law.buffalo.edu/eemeid/scholarship/FCNWRussia.pdf; Cashore et al. (eds), supra note 63. 
The emergent substantive principles governing forest certification thus include local environmental and social responsibility combined with protected property rights, stable local institutions, and effective markets. These can be read in either a 'weak' or a 'strong' way. The weak reading would suggest that the shared substantive norms are so vague and general as to provide little meaningful guidance, and so toothless as to provide few effective checks on the relentless pressures for corporate profits. The 'strong' reading would suggest that the principles reflect a significant movement toward a shared global understanding of proper forest management, and that this understanding is likely to affect practices by virtue of being embedded in a large and proliferating set of governance institutions. Not surprisingly, much of the debate on these matters has in fact taken the form of a debate about institutional arrangements. Indeed, the governing substantive principles are almost always packaged with a set of preferred institutions. The underlying assumptions are not merely that the chosen institutions will implement the principles, but that they will play a role in determining the future contents of the principles.

\section{B Form}

The FSC's certification standards are relatively prescriptive and moderately specific. The indigenous rights principle can be taken as an example:

\section{Principle 3: Indigenous Peoples' Rights}

The legal and customary rights of indigenous peoples to own, use and manage their lands, territories, and resources shall be recognized and respected. ${ }^{80}$

Each principle is further specified through 'criteria' such as the following: ...

3.3 Sites of special cultural, ecological, economic or religious significance to indigenous peoples shall be clearly identified in cooperation with such peoples, and recognized and protected by forest managers.

3.4 Indigenous peoples shall be compensated for the application of their traditional knowledge regarding the use of forest species or management systems in forest operations. This compensation shall be formally agreed upon with their free and informed consent before forest operations commence. ${ }^{81}$...

The principles and criteria are further detailed in area-specific national and regional standards, of which there are dozens. ${ }^{82}$ The US Northeast Regional standard, for example, further defines criterion 3.2 as follows:

See http://www.fsc.org/keepout/en/content_areas/77/71/files/FSC_STD_01_001_FSC_Principles_and_ Criteria_for_Forest_Stewardship_2004_04.PDF.

81 Ibid.

82 National standards are prepared for countries in which forestry conditions are comparable across areas, and regional standards for larger countries with significant variations among regions. See, e.g., the US regional standards, available at http://www.fscus.org/documents/index.php. There is an ongoing discussion in the FSC about how to define geographic areas appropriate for individual standards. 
3.2.a. Forest owners or managers identify and contact American Indian groups that have current legal or customary-use rights to the management area, and invite their participation in jointly planning forestry operations that affect their resources.

3.2.b. Forest owners or managers incorporate safeguards in management planning to ensure that management actions do not adversely affect tribal resources, either directly or indirectly. For example:

- Forest operations protect spawning and rearing areas for migratory fish harvested by Native tribes and bands.

- Forest operations maintain populations of culturally important species, such as moose, that are harvested on nearby tribal lands.

- Forest operations protect other resources identified through consultations described in 3.2a. (emphasis in original)

Although the full sets of FSC standards are much more extensive, the above examples provide enough material for the analyst of global administrative law to discern several things. First, these provisions could easily be the product of a government administrative agency - if one had ever been given such far-reaching jurisdiction. Second, although they are prescriptive, the standards leave much room for discretion. The certifier, like the government inspector, must work out their meaning on the ground. This is all the more the case because there are tensions among and within the standards. The Northeast Regional standard regarding customary community use rights makes one of them quite explicit:

2.2.a. The forest owner or manager allows customary tenure and use rights of the forest to the extent that they are consistent with the conservation of the forest resource and the objectives as stated in the management plan .... Use rights that are not legally recognized or enforceable are subject to implied or expressed consent of the landowner.

In general, the requirements of industry-based programmes tend to be both more limited and more discretionary. Thus the SFI standards generally include more flexible or discretionary provisions than the cognate FSC standards. Nonetheless, the SFI standards have gradually become somewhat more prescriptive through successive revisions. Some indicators have been converted from advisory to compulsory. The SFI and FSC standards still reflect a longstanding division about the appropriate institutional structure of certification programmes. On the one side have been proponents of FSC-style 'performance standards' and on the other those of 'management system' standards. Performance standards require the achievement of concrete conditions in the forest or in human organizations related to the forest. Management system standards focus on defining management responsibilities and processes within forest management organizations.

The font of management system standards is the ISO, and most directly the ISO 14001 environmental management system (EMS) standard mentioned above. The basic idea is to require the forest management organization to define and implement a specific set of responsibilities and processes for dealing with environmental and related issues. EMSs typically include arrangements for (1) ascertaining the organization's environmental effects; (2) planning how to increase the positive effects and/or decrease the negative ones; (3) achieving 'continuous improvement'; (4) monitoring, reporting on and correcting performance; and (5) allocating responsibilities for 
carrying out all of these functions. The underlying argument for EMSs is that harnessing the planning and control capacities of the forest management organization to the goal of improving environmental performance may achieve better results in a dynamic and uncertain environment than would reliance on fixed performance standards. ${ }^{83}$

Although the mix varies, today's forest certification programmes contain elements of both types of standards. There is some obvious intelligence in using environmental management systems, because they harness the regulated firm's internal procedures to the purposes of the regulatory programme. And this harnessing includes not only carrying out predetermined objectives, but also thinking about what the objectives should be and how best to achieve them. The difficulty is that it also allows for considerable dispute about the appropriate locus of policy-making authority. In a pure EMS system, the maximum possible amount of policy-making authority is retained in the firm. In a pure performance standard system, policy discretion in firms is minimized. Although the issue is still vigorously debated, it seems clear that over the past several years both alliances have accepted the need for a mixed system, where deliberation and policy-making occur at both the firm and programme levels.

\section{Federalism}

The discussion of performance versus environmental management system rules is one indicator of the difficulty of determining the appropriate level of centralization for making various kinds of policy decisions. Management systems approaches of course devolve maximum discretion to the lowest possible level, the individual management unit, while performance approaches tend to focus on a higher level of rule-making. The second indicator is the relationship between global, national and sub-national standards in the various certification programmes. The FSC is relatively centralized, starting with global principles and criteria and then scaling down to national and sub-national locales. The industry-based programmes are formally structured at the national level and federated into international arrangements, although the PEFC is probably better understood as having been an international European arrangement from the outset. In practice the differences between the programmes seemed to be declining for a while, but may now be expanding again. On the one hand, the FSC is becoming increasingly attuned to dealing with local variation, as exemplified by its growing stress on national initiatives and its increasingly decentralized structure. ${ }^{84}$ The PEFC, on the other

83 See, e.g., C. Coglianese and J. Nash (eds), Regulating from the Inside: Can Environmental Management Systems Achieve Policy Goals? (2001); Potoski and Prakash, 'Covenants with Weak Swords: ISO 14001 and Facilities' Environmental Performance' 24 J Policy Analysis and Management (2005) 745; Parker, 'Reinventing Regulation Within the Corporation: Compliance-Oriented Regulatory Innovation', 32 Administration and Society (2000) 529.

84 Starting in 2002 the FSC moved to create regional offices for the various continents. It has also spent considerable effort on revising its standards for accrediting national initiatives. A policy document prepared for the 2005 General Assembly in Manaus, Brazil, contains the following statement:

'In addition to globally consistent objectives, systems, quality, integrity and credibility, FSC increasingly needs regional and national flexibility in implementing its systems, standards and approaches. Different regions need to develop specific approaches to building and servicing market demand (e.g., North America, Europe), to 
hand, has sometimes seemed interested in producing more globally consistent standards and processes, but in the course of its globalization has also loosened some of its standard-setting requirements to allow greater variation. Its Executive Director continues to emphasize the importance of the subsidiarity principle in the system. ${ }^{85}$

Both alliances face considerable challenges of 'harmonization', first of standards across regions, such as the US Northeast and the US Great Lakes, next of standards for relatively similar environments across international borders, such as the US Northeast and the Canadian Maritime Provinces, and ultimately of standards for places that vary enormously. Thus, for the FSC some of the most difficult long-term challenges will involve persuading Northern consumers that timber produced by unorganized workers working for marginal corporations in developing countries, who may be using unshielded tools and wearing no protective clothing, is really the equivalent of timber produced by unionized European workers working for well capitalized corporations and using large, sophisticated machines designed for safety and wearing protective gear. Ultimately, the standardsetting processes in each programme must deal with such problems and create plausible normative understandings of what comparability means. This challenge remains largely for the future, however. For now, both the FSC and the PEFC seem to be concentrating more heavily on developing standards adapted to local conditions.

\section{Procedure}

The certification universe has seen considerable elaboration and convergence of rulemaking procedures in recent years. All certification programmes claim to be participatory and transparent. The FSC started out with relatively elaborate structures and procedures for rule-making. Not only does it have the tripartite ostensibly representative legislature of the General Assembly, but it also generally subjects new rules and policies to public notice and comment procedures analogous to those of administrative agencies in most modern governments.

The programmes in the PEFC alliance have slowly followed suit. While the SFI standards originated as products of staff members working with member companies and consumer focus groups, they now go through a web-based notice-and-comment procedure with ultimate promulgation by a multi-stakeholder governing board made

promoting and servicing market supply (e.g., Canada, Russia, tropical hardwood forests and plantations), and to linking demand and supply (e.g., China and east Asia)' (emphasis in original).

Forest Stewardship Council, FSC Strategy, 'Institutional, Organizational and Operational Development of the Global Network of the Forest Stewardship Council', Draft for Discussion by the FSC General Assembly 2005, Nov. 2005.

85 Forest Certification Watch, Interview with Heiko Liedeker, FSC's Executive Director, and Ben Gunneberg, PEFC's General Secretary, 2 July 2004, available at http://www.certificationwatch.org/ print.php3?id_article $=1845$. Subsidiarity refers to the idea that any given policy decision ought to be made at the least centralized level at which it can effectively be made. 
up of five AF\&PA members and 10 outsiders chosen from academia, state and local agencies, professional associations and environmental groups. ${ }^{86}$

Most rule-making in the PEFC alliance is done at the national level. National programmes were originally expected to fall within the general criteria of sustainability developed by the Pan-European Ministerial Conferences, but can now be based on a broader set of processes. The standard procedure for each country is roughly as follows: (1) an existing forest owners' organization invites other national organizations representing 'relevant and interested parties' to constitute a 'national governing body for the programme'; (2) the national governing body constitutes a forum, again inviting all relevant parties (e.g., forest owners, trade unions, NGOs), and then develops a certification programme appropriate to that country; (3) the resulting programme is submitted to the PEFC, which appoints external consultants to prepare a report assessing the proposed programme under PEFC criteria; (4) the consultant reviews the programme and invites comments from 'all interested parties' ${ }^{87}$ and then makes a recommendation to the PEFC, which (5) ultimately decides whether to endorse the programme.

In sum, all of the major programmes now employ notice and comment procedures, and provide for at least some stakeholder involvement. The PEFC processes are still ultimately controlled by landholder and industry groups, who choose which additional stakeholders are included in the decisional process. The FSC at least requires a tripartite structure with equally distributed voting power, but it should be noted that the FSC still exerts some control on who can join in that an applicant must be supported by at least two existing members.

The effort to define appropriate rule-making processes for trans-governmental standard setting is still very much in process. The ISEAL Alliance recently developed a 'code of good practice' for social and environmental standard setting which it presumably believes will contribute to the legitimacy of certification programme standards. ${ }^{88}$ Many of the guidelines are framed in language that could as well be used by government agencies - and indeed, the guidelines are written to be equally applicable to governmental and non-governmental processes. Standard-setting processes should (1) follow documented procedures; (2) consider comments on the need for and objectives of the standard; (3) allow two rounds of public comment on proposed standards; (4) keep a record of the standard-setting process; and (5) produce a written, publicly available synopsis of how each material issue raised in the comments was addressed in the standard. ${ }^{89}$ Except for the multiple comment period requirements, the guidelines could have been taken directly from the US Administrative Procedure Act, and no doubt those of other countries as well.

86 Sustainable Forestry Board, available at http://www.afandpa.org/Content/NavigationMenu/ Environment_and_Recycling/SFI/Sustainable_Forestry_Board/Sustainable_Forestry_Board.htm.

87 Solicitations for comments on proposed Brazilian, Slovak, and Estonian endorsements are posted on the PEFC website at this writing: see http://www.pefc.org/internet/html/.

88 ISEAL Code of Good Practice for Setting Social and Environmental Standards. P004 - Version 3 - Jan. 2004, available at http://inni.pacinst.org/inni/General/ISEALCodeFinal.pdf.

89 Ibid., section 5. 
Many government agencies, however, operate under delegated authority from representative democracies. Trans-governmental rule-making processes generally do not. Seeking to draw upon and extend directions drawn from ISO and WTO guidelines, ${ }^{90}$ the ISEAL code addresses this problem by mandating that standard setting 'strive for consensus among a balance of interested parties'. The definition of consensus is drawn from the ISO:

3.1 Consensus: General agreement, characterized by the absence of sustained opposition to substantial issues by any important part of the concerned interests and by a process seeking to take into account the views of interested parties, particularly those directly affected, and to reconcile any conflicting arguments.

Note - Consensus need not imply unanimity. ${ }^{91}$

'Interested party' is defined liberally by ISEAL as 'any person or group concerned with or directly affected by a standard' ${ }^{92}$ Furthermore, the ISEAL standard provides that the '[s]tandard setting organization shall ensure that participation reflects a balance of interests among interested parties in the subject matter and in the geographic scope to which the standard applies"93 and that "no group of interested parties can dominate nor be dominated in the decision-making process'. Thus, in this vision a rule is legitimated by the participation (or at least opportunity to participate) in a consensus decision process of all who are affected or concerned. This is not yet the practice of all forest certification programmes. The FSC is easily the farthest along, but has also had some problems with implementation. In the regional standard-setting processes for the Canadian Maritimes and British Columbia, for example, one of two economic seats in the working group was allocated to a representative of large industry; the other went to a small operator. In both cases the large industry representatives were sufficiently dissatisfied to stop participating in the process and were not part of the 'consensus' that eventually was obtained. Although the resulting standards were both initially accepted by FSC international, they caused considerable consternation and ultimately appear to have led to a change in the FSC's applied understanding of consensus so that industry acceptance of the standards is expected. The PEFC is moving on these issues, but much more slowly. It provides for notice and comment but does not require broad-based participation or acceptance in national standard setting. Nonetheless, the general tendency to extend procedural and structural participation

ISO/IEC Guide 2:1996, 'Standardization and related activities - General vocabulary'; ISO/IEC Guide 59:1994, 'Code of good practice for standardization'; ISO/IEC Guide 14024:1999, 'Environmental labels and declarations - Type 1 environmental labelling - Principles and procedures'; WTO Agreement on the Application of Sanitary and Phytosanitary Measures (SPS); WTO Agreement on Technical Barriers to Trade (TBT), Annex 3: Code of good practice for the preparation, adoption and application of standards; WTO Agreement on Technical Barriers to Trade (TBT) Second Triennial Review, Annex 4: Principles for the Development of International Standards, Guides and Recommendations with Relation to Arts 2, 5, and Annex 3 of the Agreement.

92 ISEAL Code, supra note 88, Sect. 3.2. This is a relatively broad definition. Some standard-setting organizations limit the term to those who are directly affected by standards. ISO 14004 opted for the broader definition, however.

93 Ibid., Sect. 7.1. 
may reflect the underlying conceptual pull of the concept of participation with which the programmes are contending. ${ }^{94}$

The underlying idea is that a standard will be good, and presumably legitimate, if it reflects the priorities of interested parties. While this concept of the public interest is not free of theoretical problems, it is difficult to argue that interested parties should not be heard, and it is also difficult to argue that a standard which receives the assent of all affected and concerned parties is bad. Finally, of course this vision has had a significant influence on concepts of governmental decision-making as well, perhaps because delegations of authority from elected bodies implemented by expert agencies are not always enough to produce well-accepted standards.

\section{Adjudication and Enforcement}

The significance of forest management standards is largely a function of the degree to which they are put into practice on the ground. Given the incentives of firms to minimize costs, certification programmes must have methods for judging and enforcing compliance. These are conventionally broken down into three functions: certification, accreditation and labelling.

\section{A Certification}

Assessing the eligibility of forest management operations for certification is the primary adjudicatory process of the global forest regulatory system. Certifying good forest management is the main reason that certification programmes exist. Certification programmes must persuade observers that they reliably distinguish good forest management from bad. There has been much debate among and within programmes about the institutional arrangements necessary to make this process work. Some of the issues concern procedures, others qualifications of certifiers. The typical certification procedure as instituted by the FSC involves the following steps:

(1) preliminary discussions between the potential applicant and one or more certifiers, including indications of what changes the applicant likely would have to make to achieve certification;

(2) submission of an application to a certifier, including documentation of the applicant's operation;

(3) negotiation of a budget and other contractual terms of the assessment, possibly including a 'scoping' process;

(4) an on-the-ground field assessment, including:

(a) review by an interdisciplinary team that would typically be made up of several individuals, including forestry, biology and social science experts;

94 Margaret Shannon argues that unconstrained participation is inherent in the concept of sustainable governance: Shannon, 'What is Meant by Public Participation in Forest Certification Processes? Understanding Forest Certification Within Democratic Governance Institutions', in Meidinger, Elliott, and Oesten, Social and Political Dimensions of Forest Certification, supra note 40, at 179. 
(b) consultations with local stakeholders; $;^{95}$

(5) preparation of a draft assessment report by the certifier;

(6) peer review of the report by two or three independent specialists; ${ }^{96}$

(7) discussion of possible terms and conditions of certification with the applicant;

(8) a final certification decision (see below);

(9) issuance of a certificate, processing of final payments, further certification contracts, press releases, etc; and

(10) annual follow-up audits

Certifiers have several options in reaching a final decision on certification: (1) approve the application unconditionally; (2) grant provisional approval on condition that specified 'corrective actions' are taken to rectify specified 'minor non-compliances' within a certain time; (3) indicate that approval will be granted after certain 'major non-compliances' are corrected; or (4) deny the application. The bulk of FSC certification proceedings seem to result in the second option: provisional approval with corrective action requirements. ${ }^{97}$ FSC certificates ordinarily last for five years, after which time a thoroughgoing reassessment takes place prior to renewal.

Several things about the FSC process deserve note. On the positive side, it requires an on-the-ground inspection as well as consultation with local stakeholders. It thus combines the often separate permitting, hearing and inspection processes that might typify, for example, the granting of a discharge permit under the US Clean Water Act. It also involves probably more public participation than the typical notice and comment process in a discharge permit, since the certifier is expected to seek out public comment, rather than simply receive it. Although the FSC procedure was initially the only one to require local stakeholder consultations, the PEFC has very recently changed its policy to require local consultations as well; what this will mean in practice remains to be seen. ${ }^{98}$

On the other hand, although required by the FSC to be a "third party' ${ }^{\text {'9 }}$ - that is, neither an employee of the firm, nor one of its customers or suppliers - the certifier is selected and paid by the organization seeking certification. This poses a problem which can be seen either as a vague tendency to favour the applicant where standards are indeterminate or as a structural risk of corruption, depending on one's

95 Most stakeholder consultation processes to date have been developed by certification organizations. The FSC is working to systematize information on and approaches to local consultation.

96 In order to reduce costs, the peer review requirement does not apply in FSC's programme for Small and Low Intensity Managed Forests, essentially small operations and operations that do not carry out intensive logging. See http://www.fsc.org/slimf/.

97 Thornber, 'Overview of Global Trends in FSC Certificates: Instruments for Sustainable Private Sector Forestry', Report of the International Institute for Environment and Development (IIED) (1999).

98 PEFC press release, 12 April 2005, available at http://www.pefc.org/internet/html/news/4_1154_65/ 5_1105_1174.htm.

99 Although the FSC has required third party verification from the beginning, the other programmes made it optional to various degrees. There has been a long evolution among them encouraging and gradually urging or requiring third party verification, but this has been largely tied to labelling requirements, discussed below. 
perspective. The FSC attempts to deal with this problem by reviewing selected accreditation decisions of certifiers, with the option of suspending or revoking their status as certifiers if problems occur, and also by steadily increasing the level of transparency of certification proceedings, as discussed below.

The FSC has a procedure for handling complaints about certification decisions, but it is relatively cumbersome and constrained. Only FSC members are allowed to lodge complaints; thus non-members must bring complaints to the FSC through members. ${ }^{100}$ Before lodging a complaint a member must make reasonable attempts to resolve the dispute informally. When a complaint is filed it first goes through an 'informal' stage, which is basically a mediation handled by either a Board member or the chair of the Dispute Resolution Committee. If that does not resolve the issue the dispute can move to a second 'formal' stage, which requires that two members file a formal complaint and that they post funds to cover possible costs of the process. This stage is basically a 'paper hearing', with either the Board or the Dispute Resolution Committee reviewing written filings. The decision-making body also has discretion to invite oral presentations or make site visits. Decisions by the Board may be appealed to the Committee, but there is no appeal from decisions of the Committee. ${ }^{101}$ Apart from the requirement that complainants be prepared to pay the costs, the FSC process is not very different from the informal adjudication procedures common in state-based legal systems, which are also often limited to a narrow set of parties, and indeed frequently may be initiated only by government officials or regulated parties.

While the official dispute resolution procedure is relevant, it is also the case that the FSC International Secretariat, Board, and National Initiatives are likely to respond to serious allegations of problems beyond the formalities of the procedure. This indeed has happened in many cases. There are real questions, however, whether either process is adequate to handle the pervasive benefit-of-the-doubt dynamics that are likely to characterize many certification processes. The SFI and PEFC also face this problem, and probably more severely in that certifiers have considerably more discretion in their programmes, but they try to distance themselves from the problem in different ways. For the PEFC, it is up to the national certification programme to decide how to handle complaints and disputes, although none of the various national programme approaches studied to date seem very rigorous or transparent. The SFI has gradually expanded its programme from one in which loggers can confidentially report 'inconsistent practices' to the Sustainable Forestry Board to one in which 'any party' can challenge a certification before a Special Appeals

${ }^{100}$ FSC Interim Dispute Resolution Protocol, Approved by the Board, 27 Jan. 1998, FSC Document 1.4.3, available at http://www.fsc.org/keepout/en/content_areas/77/47/files/Interim_Dispute_Resolution_ Protocol.PDF. The FSC is currently working to revise its dispute resolution protocol, and ongoing discussions suggest that it is likely to loosen some of the constraints in the current system and as well as reduce the number of steps.

101 The Committee is most likely to be the first decision-maker in complaints involving decisions of the Board. Otherwise the Board is likely to be the first decision-maker, although it may choose to send a dispute directly to the Committee: ibid., para. 21. 
Subcommittee of the Board. ${ }^{102}$ While all of the procedures are constrained in one way or another, they seem to be expanding.

The tendency of certification programmes to repose so much trust in certifiers is difficult to explain. Some of it probably has to do with a general technocratic confidence in expertise, together with the particular history of the forestry profession in gathering a high level of public trust to itself over generations. Such reliance seems likely to prove more fragile in forest certification than in some other types of private certification programmes. This is because buyers of certified products are less likely to discover poor certification work than would be the case where the certified product in fact performs poorly in the use to which it is put.

Additionally, most of the information in the work products of the certification process belongs to the applicant after the certification decision is made. However, the tendency is to disclose an increasing amount of such information. The FSC requires that the certifier prepare a public certification summary containing sufficient information to make clear the correlation between the specific results of the certification assessment and FSC principles'. ${ }^{103}$ This must be available on a website and must be in the main local native language and in one of the official languages of the FSC (English and Spanish). ${ }^{104}$ It must also include a description of the certification process, the qualifications of the certification team, and any corrective action requests. ${ }^{105}$ These public information requirements have been gradually expanded over time, and until recently greatly exceeded those imposed by other programmes, where the main public administrative record would simply be a yes/no answer. The PEFC recently announced that it has changed its policy to require that a summary of each certification audit be made available to the public. ${ }^{106}$ Both this change and the PEFC's decision to require local stakeholder consultations were driven by the UK government's purchasing policy criteria, which require such policies in order for certified products to be eligible for government purchasing. Limited as the public information requirements of the more conservative forest certification programmes are, it should be noted that they may be equal to or greater than most government reporting of inspection results.

102 SFI Audit Procedures and Qualifications, Section 9.3.2, Disputes or Appeals Questioning the Validity of a Certification (http://www.aboutsfb.org/generalPDFs/SFBStandard2005-2009.pdf). The complainant must first bring the problem to the attention of the certified programme participant, but if not satisfied after 45 days can take it to the President of the Sustainable Forestry Board, who sends it to the Certification Appeals Subcommittee, which decides whether to pursue the matter or close it.

103 Amended Motion 26A, 1999 General Assembly, available at http://www.fsc.org/keepout/en/ content_areas/77/76/files/FSC_General_Assembly_1999_Final_Motions.pdf. This has since been elaborated into a detailed set of requirements in the Accreditation Standard: Forest Certification Public Summary Reports, FSC Std 20-009, Version 2.1, available at http://www.fsc.org/keepout/en/ content_areas/77/106/files/FSC_STD_20_009_Public_summaries_V2_1.PDF.

104 Ibid.

105 Ibid.

106 Press Release, 12 April 2005, supra note 98. 


\section{Accreditation}

Given their heavy reliance on certifier expertise and credibility, much debate among forest certification programmes has focused on what qualifications certifiers should have and how they should be accredited. The FSC conducts its own relatively intensive accreditation processes, and currently lists 15 accredited certification organizations. ${ }^{107}$ As noted above, it also reviews the work of certifiers and on several occasions has suspended the accreditation status of certifiers. ${ }^{108}$ The FSC recently reviewed its overall accreditation programme to bring it in line with ISO protocols. ${ }^{109}$ It has also spun off the accreditation unit into an independently registered company and required it to be financially self-sustaining. ${ }^{110}$ Most other forest certification programmes rely directly on general ISO-affiliated accreditation programmes, which are usually nationally based and carry out multiple types of certifications in a variety of non-forestry programmes. The SFI, for example, requires that the leader of any thirdparty verification team be accredited as an 'environmental management systems lead auditor' under the appropriate ISO-affiliated national accreditation body, ${ }^{111}$ that a professional forester serve on each team, and that the team include expertise in wildlife ecology, silviculture, forest hydrology and operations (not necessarily in separate individuals). ${ }^{112}$

\section{Labelling}

Because forest certification programmes are centred on the idea of certifying the propriety of wood products to downstream market participants, their policies for labelling those products have become increasingly important. There are two basic dimensions to these policies. The first involves the need to distinguish certified from uncertified wood through what are often very complex production chains. The 'chain of custody' policies ${ }^{113}$ vary among the certifying organizations, but even the relatively stringent FSC allows use of the FSC logo on products that do not consist entirely of FSC-certified fibre. The second has to do with the claims that are made on the products. These are dealt with through increasingly detailed and stringent controls on the use of programme-based labels. The controls are structured and enforced largely

107 FSC Accredited Certification Bodies, available at http://www.fsc.org/en/about/accreditation/ accred_certbod.

108 E.g., FSC Press Release, 'FSC Reinstates Skal Chain of Custody Accreditation', 16 May 2001, available at http://www.forestrycenter.org/headlines.cfm?RefID=74391.

109 FSC Accreditation Process for Applicant Certification Bodies, 18 Jan. 2004, available at http:// www.fsc.org/keepout/en/content_areas/77/35/files/ABU_GUI_10_111_final.pdf.

110 Report by Alistair Monument, head of the Accreditation Business Unit, to the FSC General Assembly in Manaus, Brazil, 7 Dec. 2005.

111 Examples include the American National Standards Institute/Registrar Accreditation Board and the Canadian Environmental Auditing Association. This requirement only becomes effective one year after the relevant national accreditation body accepts SFI audit experience as appropriate for meeting its experience requirements.

112 The SFB does have a 'verifiers accreditation subcommittee', however, and it is possible that more requirements will be introduced. See http://www.aboutsfb.org/committees.cfm.

113 FSC Chain of Custody Policy, available at http://www.fsc.org/coc/. PEFC Chain of Custody Policy, available at http://www.pefc.org/internet/resources/5_1177_452_file.1299.pdf. 
through national and international trademark law. Each forest certification programme has developed a logo or set of logos to signify the status of the product within its programme, ${ }^{114}$ as well as detailed policies with regard to use of logos. Recently, logos have become increasingly complex, with both the FSC and the PEFC having different versions depending on the claim being made. ${ }^{115}$ Like many other elements of the programmes, these logo policies seem to be converging to some extent, perhaps in part because they operate in the same world of trademark law and in part because they respond to the same complexities in international timber markets.

\section{B Enforcement}

Because certification programmes are self-defined as voluntary, it is not surprising that formally they have few enforcement mechanisms. The official enforcement mechanisms of most forest certification programmes are limited to revoking the certification itself or to revoking membership in the related association. ${ }^{116}$ In fact, however, the enforcement system is more extensive than this. First, certified forestry companies are engaged in increasingly well-controlled product chains. If their customers are committed to buying certified products, loss of a certificate is likely to be accompanied by loss of business. This has occurred in several cases and serves as an important sanction for failing to demonstrate compliance with certification standards. Second, as described above, many major retailers have committed to carrying certified products at least in part because they are under steady pressure to do so. The Forest Campaigners regularly scan the forest products trading system for vulnerable targets - and potential targets know this, much as they may resent it. Thus external scrutiny by activist groups, and the possible bad or good publicity they can provide often serve as powerful sanctions, particularly for branded companies. ${ }^{117}$ Finally, the multiple institutionalization of forest certification seems to be developing its own momentum. The further the forestry industry goes down the road of certification, and the more institutionalized its direction becomes in the various ways described above, the less likely it is to reverse course. This process by which procedures and expectations are routinized and institutionalized may be as important in the long run as the search for market share and the
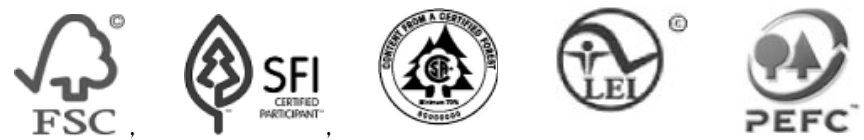

115 Supra note 113.

116 This is the sanction the AF\&PA retains in regard to SFI, but in order to suffer it a company must actually refuse to apply the principles of the programme even to the extent of self-regulating. Retaining membership does not require subscribing to third-party certification: SFI Audit Procedures and Qualifications, Sect. 1, Scope, available at www.aboutsfb.org/generalPDFs/SFBStandard2005-2009.pdf.

117 See Sasser, supra note 61.
} 
risk of reputational attacks in enforcing certification standards, although it would be unlikely to proceed without them. ${ }^{118}$

\section{Preliminary Assessment}

The system of global forestry regulation described in the preceding sections has been built with remarkably little direct involvement by state or interstate administrative agencies. Yet it operates a sophisticated, evolving and rapidly expanding set of administrative regulatory institutions. So similar are they to their better known state cousins that they virtually cry out for assessment according to the received criteria of administrative law. The analysis involved is not likely to be a one-way process, however. Although it is important to apply the received criteria of administrative law to these emergent institutions, it is equally important to glean lessons from them that can be taken back to the analysis of governmental administrative institutions.

Many criteria are regularly used to assess administrative institutions. Traditional ones in American public law scholarship include accuracy, fairness, effectiveness, efficiency, public acceptability and fidelity to law, as well as somewhat more conceptually intricate ones such as accountability, responsiveness, democracy and legitimacy. Most of these criteria are intertwined to some extent, seeming separable only at a very abstract level, and can therefore be mixed and matched in various ways as applied to empirical phenomena. The major questions about trans-governmental regulatory institutions to date seem to revolve around three basic issues: their effectiveness, their accuracy or reliability, and their legitimacy, and the discussion below is organized in terms of these. For reasons of theory explained below, however, the discussion of legitimacy is framed in terms of the criterion of accountability.

\section{A Effectiveness}

Much scholarly discussion of forest certification to date has concentrated on the question of effectiveness. This discussion can be organized in terms of three main issues: adoption, behavioural effects, and adaptability or learning capacity. Much of the early analysis has focused on the preliminary question of adoption. Boiled down to its essentials, the conventional wisdom has been that forest certification is unlikely to work or to persist because it is unlikely to be widely adopted. The simplest version of

118 There are several perspectives in organization theory on why embedded routines persist. In general, see DiMaggio and Powell, ' The Iron Cage Revisited: Institutional Isomorphism and Collective Rationality in Organizational Fields', 48 American Sociological Rev (1983) 147. For perspectives emphasizing the importance of cultural understandings, see Zucker, 'The Role of Institutionalization in Cultural Persistence', 42 American Sociological Rev (1977) 726, and also the classic by P. Berger and T. Luckman, The Social Construction of Reality: a Treatise on the Sociology of Knowledge (1966), esp. at 95-96. For interestbased models, see, e.g., David, 'Clio and the Economics of QWERTY', 75 American Economic Rev (1985) 332 and Pierson, 'Increasing Returns, Path Dependence, and the Study of Politics', 94 American Political Science Rev (2000) 251. For a recent synthesis see Colyvas and Powell, 'Roads to Institutionalization', in B. Staw (ed.), Research in Organizational Behavior, 11/05, available at http://www.stanford.edu/group/ song/papers/colyvas_powell.pdf. 
this thesis has focused on the fact that there is notably little demand among retail consumers for certified forest products (although it is slowly growing). What demand exists becomes minuscule when willingness to pay is considered; very few retail consumers seem willing to pay price premiums for certified forest products. And yet, forest certification is spreading rapidly, and engaging and structuring a growing share of the world's forestry industry. At this writing approximately seven per cent of the world's forests are certified through one programme or another, and the amount of certified area continues to grow rapidly. The reasons for this growth remain widely debated, but seem to boil down to a few primary factors that have already been discussed. The main driver has been the ability of environmental NGOs to pose risks to markets in Europe and North America, and to leverage brand values to this end. But as suggested above, this leverage seems to exist in part because of the widespread acceptance of the values promoted by the certification movement, and because of the inability of the governmental regulatory system to institute them.

More importantly, the spread of forest certification is having some effect on forestry practices. Most informed researchers seem to agree that forest certification is having impacts both on the normative frameworks of the forestry world and on the actual practices of forestry operations - not all of them, certainly, but a growing proportion. ${ }^{119}$ These effects vary widely by country and region, ${ }^{120}$ and sometimes are tangled up with other ongoing changes such as economic restructuring, but there is a great deal of evidence that the adoption of certification programmes has improved environmental and social practices in many parts of the world. ${ }^{121}$ Moreover, the process of establishing certification programmes has often had significant effects on forest policy more generally. ${ }^{122}$ On the other hand, there is a growing body of research indicating that both the adoption and effectiveness of forest certification depend to a significant extent on the governmental regime operating in the

119 S. Bass et al. (eds), Certification's Impacts on Forests, Stakeholders and Supply Chains, Report of the International Institute for Environment and Development (May 2001); Nussbaum and Simula, 'Forest Certificaion: A Review of Impacts and Assessment Frameworks', paper prepared for The Forest Dialogue (2004), executive summary available at http://research.yale.edu/gisf/assets/pdf/tfd/certreview.pdf: Cashore, Gale, Meidinger, and Newsom, supra note 63. Certification is disproportionately concentrated in relatively developed countries, however, and has taken hold much more slowly in most developing countries.

120 Ibid.

121 See, in addition, e.g., D. Newsom, V. Bahn, and B. Cashore, Does Forest Certification Matter? An Analysis of Operation-Level Changes Required During the SmartWood Certification Process in the United States, manuscript on file with author, 9 May 2005; Spillsbury, 'The Sustainability of Forest Management: Assessing the Impact of CIFOR Criteria and Indicators Research', CIFOR Impact Assessment Papers No. 4 (2005), available at www.cifor.cgiar.org/publications/pdf_files/Books/BSpilsbury0503.pdf. For an arguably self-interested, yet interesting, set of reports see WWF European Forest Programme, 'The Effects of FSC Certification in Estonia, Germany, Latvia, Russia, Sweden and the UK: An Analysis of Corrective Action Requests Summary Report', available at http://www.panda.org/about_wwf/where_we_work/europe/ where/uk/publications/index.cfm? uNewsID $=18510$, as well as the individual country reports linked to the website.

122 E.g., Bass, 'Certification in the Forest Political Landscape', in Meidinger, Elliott, and Oesten, supra note 4, at 27 . 
locality. If governmental standards and enforcement are reasonably good in a given jurisdiction, certification is more likely to be adopted and, at least if it is FSC certification, is also likely to push management standards upward, in both the environmental and social dimensions. ${ }^{123}$ Conversely, certification is more difficult to adopt and effectuate in jurisdictions where government regulatory institutions are weak or corrupt. Thus, importantly if not surprisingly, the capacity of forest certification to improve forest management is tied to the general institutional context in which it operates. This means that forest certification is not the 'silver bullet' for the worst cases of forest destruction that some of its proponents may have hoped for, but it has made important contributions to stabilizing and improving forest management in many places. It also means that an important next step for research will be to learn more about how forest certification interacts with local community and state institutional structures, and potentially to pinpoint key improvements that might be made in those structures in tandem with a move to forest certification.

One of the most striking changes in the forestry regulatory system since the appearance of forest certification has been its growing dynamism. Almost everywhere forest certification has come into play, it has spurred new debates about proper forest management and at least some new mechanisms for testing and monitoring it. Generally, as described above, the adoption of FSC certification has spurred establishment of competing landowner and industry-based programmes, which in turn have created a challenging and competitive environment for the FSC. Debate among and within programmes is increasingly widespread, and the search for advantage intense. Where one programme seems to have a weakness, a competing programme is likely to quickly point it out and to try to provide an alternative. Of course, not all of the claims and counterclaims are free of hyperbole or partial accuracy. But a considerable amount of information about the functioning and problems of forestry appears to be generated by the process. That information sometimes also involves or influences government programmes, perhaps most often through small, incremental steps such as changes in enforcement practices or interpretations of regulations, but sometimes also through changes in formal requirements. While the overall system is too complex and fluid to draw definite conclusions, there are preliminary grounds for believing that it is exhibiting a growing capacity for learning and adaptation, due in large part to the competition among programmes and perhaps to a lesser degree to the commitment to continuous improvement in management systems. The rapid flows of information and broad multi-stakeholder dialogue and debate also appear to be valuable mechanisms of adaptation. Whether this will turn out as socially beneficial learning, as opposed to opportunistic manoeuvring, remains to be seen. But it seems clear that adaptive dynamics are important, given the great complexity and dynamism of forest ecosystems and global markets, and our very limited understanding of

123 See Cashore, Gale, Meidinger, and Newsom, supra note 63; Ebeling, 'Market-based Conservation and Global Governance: Can Forest Certification Compensate for Poor Environmental Law Enforcement? Insights from Ecuador and Bolivia', thesis presented to the Albert-Ludwigs Universität Freiburg in partial fulfillment of the requirements for the degree of Magister Artium in Political Science, June 2005. 
them. Thus, if a more adaptive forest regulatory system is indeed emerging, that is likely to be a very important development for its overall capacity to achieve sustainable human-forest relationships.

This is not the place to expound on why traditional consumer-based economic models of regulatory institutions seem to come up short in the case of forest certification. Indeed, it is not the place to develop a thoroughgoing explanation of the rise of forest certification per se. ${ }^{124}$ But, in order to assess the implications of forest certification it is necessary to offer at least a tentative theory of why it has been so effective thus far. The most obvious way to do this is through a particular kind of legal institutional theory, one which, unlike many functionalist institutional theories, accords a causal role to normative vision and to political movements seeking to implement that vision. The rise of forest certification was driven by social movement actors with a vision of, to put it in a slightly grandiloquent way, 'the just forest'. This is a forest in which basic ecological functions are protected, workers and forest-dependent communities sustained, and economic transactions with the world economy maintained over the long term. It is the expansive vision of sustainable forest management discussed above.

This vision seems to have been influential for three basic reasons. First, its proponents have framed it in a rhetorically powerful way. It is not easy to be against sustainable forestry, nor for the destruction of forest environments or communities. Moreover, the forest campaigners used the latent voice of potentially disapproving consumers to translate it into market pressure in the form of risks to valuable brands. Second, proponents have packaged this vision in conventional, widely acceptable standard-setting and enforcement institutions that are commonplace and fairly easy to coordinate with modern management organizations. Third, they have used existing power structures, particularly global trading networks, to leverage those institutions into place. It is important to stress, however, that they have been very careful in choosing their enemies, and have tried to make peace with the global economy wherever possible. Functional variables therefore also play a powerful role in explaining institutional adoption.

\section{B Reliability}

To say that a regulatory system is effective in shaping the objectives and behaviour of economic actors is not necessarily to say that it is a form of good regulatory administration. Modern administrative systems are expected to make reliable decisions - meaning impartial, accurate and consistent ones. Because these criteria are virtually impossible to assess on their own terms in most real world situations, administrative law scholars generally rely on institutional proxies to address them. Traditionally, these have included the use of independent experts, the maintenance of official neutrality, and the availability of review and appeals mechanisms. By these standards the forest certification system as it exists today can be seen in either a positive or a negative light.

124 This effort is moving forward, however. For recent examples, see Bartley, supra note 62, Cashore, Auld, and Newsom, supra note 19, and Pattberg, The Institutionalization of Private Governance: How Business and Nonprofit Organizations Agree on Transnational Rules', 18 Governance: An International Journal of Policy, Administration, and Institutions (2005) 589. 
On the negative side, there is a major problem of competing certification programmes with inconsistent and contested standards. Thus, one certification mark is not the equivalent of another and one certified forest product may have quite a different environmental and social pedigree than another. But this is not necessarily an insoluble obstacle to certification-based forestry governance, since the marks are different and information is fairly readily available on their meaning. Moreover, a general understanding of the relative status of the marks could develop over time.

Even within certification programmes, however, there are reasons for concern. While all of the programmes rely on experts, and there is no reason to think that the experts are less intelligent or well educated than they would be if they worked for state agencies, they are chosen and employed by the firms seeking certification, rather than by a state agency. This has the advantage of removing the costs from the public treasury, but involves real risks of certifier bias and inconsistency. The seriousness of this problem is difficult to gauge at present. Certification programmes seem confident that it will not undermine their credibility. But the basis of their confidence is unclear. To the degree that they are simply mimicking the practices of traditional technical standard-setting programmes, they may be misguided. In most technical certification processes problems of functionality are likely to emerge if sub-standard products are certified. The poor work will thus be discovered and the party needing certification is likely to find a different certifier. This is not the case for forest certification; a wood product is likely to perform its function equally well whether it was produced through sustainable forest management or not.

On the other hand, the larger competitive and political dynamics of the forest certification world may serve to reduce the risks of certifier bias somewhat or perhaps even considerably. Many actors have interests in pointing out sub-standard certifications, and indeed have done so quite loudly in a number of cases. ${ }^{125}$ The programmes also have some internal review processes that will catch at least some problems, such as the FSC auditing programme and the SFI 'inconsistent practices' reporting mechanism. There are also other dispute resolution possibilities, but on the whole they are relatively limited and difficult to pursue. The availability of these procedures seems likely to remain quite limited, given the pressures on certification programmes to keep down costs.

\section{Accountability}

Accountability has emerged as a central term in discussions of non-conventional regulatory institutions. There may not be a simple explanation for this development, but

125 E.g., Counsell and Terje Loraas, 'Trading in Credibility: the Myth and Reality of the Forest Stewardship Council', Report of the Rainforest Foundation (2002), available at http://www.rainforestfoundationuk.org/files/Trading\%20in\%20Credibility\%20full\%20report.pdf; Carrere, 'Certifying the Uncertifiable: FSC Certification of Tree Plantations in Thailand and Brazil', Report of the World Rainforest Movement (2003), available at http://www.wrm.org.uy/actors/FSC/text.pdf. These reports are both attacks on the FSC policy for certifying forest plantations. Plantations policy is currently a major point of contention both in the FSC and among environmentalists, many of whom argue that plantations are destructive monocultures consistent only with destructive industrial forest practices, but a growing number of whom argue that plantations are desirable ways of protecting natural forests, particularly in tropical regions. 
one possible cause is a growing discomfort with the term 'legitimacy'. Legitimacy was once a genealogical term for most legal (as opposed to socio-legal) scholars: ${ }^{126}$ administrative policy and decisions were legitimate if they could be traced to a properly functioning organ of a state; states themselves were presumptively legitimate. Legal scholars could thus concentrate on the practical business of how close the linkage of administration to state policy should be and how it could be maintained. Legal scholars have been open-minded enough to acknowledge that administrative regulation without clear ties to state legitimacy might conceivably still be legitimate somehow, but have not been prepared to carry the heavy normative load involved in making that assessment. Hence the attractiveness of accountability. Accountability seems to be a relatively open concept. An administrative system could possibly be accountable to many different sources of authority, but at least it would be accountable.

And yet, the term accountability poses the same conundrums as legitimacy in the end. One must answer the question, accountable to whom or what? And one must still make a judgment about the validity of the source of authority. Indeed, the underlying principalagent connotations of the term may cause further problems by allowing the analyst too easily to focus on and critique one or another source of accountability in isolation - NGOs by themselves, for example, or industry associations by themselves - when in fact accountability mechanisms are cumulative and interactive. This problem can be put off to some extent by focusing on institutional proxies for accountability, two of which on the $e x$ ante side are transparency and participation mechanisms. These can be considered before returning to the larger question of accountability in forest certification.

\section{Transparency}

All of the forest certification programmes embrace the value of transparency and claim to be transparent. But their transparency remains limited, particularly in the case of the industry programmes. On the whole, it focuses on rule-making rather than adjudication and other forms of administrative decision-making. As noted above, public information on certification inspections is limited, partly because much of it is seen as confidential business information that, if made public, could injure the competitive position of the firm. The FSC has always mandated more disclosure than the industry programmes, ${ }^{127}$ but some of the industry programmes are also beginning

126 Most were never completely comfortable with the Weberian version of the concept - the ability of a legal system to elicit compliance without using coercion even from those who disagreed with the rule involved: M. Weber, Economy and Society: an Outline of Interpretive Sociology (ed. G. Roth and C. Wittich, trans. E. Fischoff et al., 1978, orig. 1922), at 31. For an illuminating analysis of the genealogical conception of legitimacy see E. Rubin, Beyond Camelot: Rethinking Politics and Law for the Modern State (2005), ch. 5.

127 The 2005 FSC General Assembly in Manaus, Brazil, approved a resolution for the development of guidance on the participation of observers in forest management assessments and audits. The guidance is to discuss criteria for selection and acceptance or rejection of observers, how they will be involved in the certification process, confidentiality requirements, observer conduct, and costs: Amended Motion 14, 2005 General Assembly of the Forest Stewardship Council. This seems to move the FSC in the direction of making observer access to certification inspections commonplace and routine. The motion was widely supported, even by forest managers, evidently on the premise that it will contribute significantly to the credibility of the programme. 
to provide more public information on inspections. This appears to be due largely to emerging public procurement requirements in Europe, but these requirements themselves may reflect the practical power of the concept of transparency. If a significant amount of information about a given practice is publicly available, then that practice becomes potentially accountable to a broad set of actors and values, at least in that it is subject to their criticism. The public has the capacity to withdraw its approval of the practice. If criticism or public disapproval does not materialize, the practice may become implicitly more legitimate.

On the other hand, the very rise of forest certification may also have been tied to a desire to limit the transparency of forest management. Thus, one attraction of certification programmes to firms is that they implicitly provide cover for the firms. Rather than having the public or nosy government inspectors intruding into their operations, the firms hire certifiers to perform inspections and then to stand between the firms and the public with a simple yes/no summary of findings. Of course, the situation would be little better and probably worse with a government inspectorate. Absent statutory directives, most inspectorates seem to treat information from inspections as privileged in one way or another, and are loath to release it. The fact that the amount of public information on certification inspections is increasing may portend a general movement toward greater transparency in forestry regulation, but this remains to be seen. The forestry world has a long history of fairly constrained information flows, and there are continuing pressures to return to those ways. Transparency in this field, therefore, remains a work in progress.

\section{Participation}

As Section 2 showed, the forest certification programmes are gradually expanding their provisions for public participation. On the procedural side, largely driven by the FSC model, they have all adopted at least minimal notice-and-comment procedures. ${ }^{128}$ Yet as in government agencies, a great deal of decision-making can take place before the notice process begins. Moreover, the comments may play only a small role in determining the ultimate content of the rules.

More generally, forest certification programmes seem to be spurring an increase in the overall amount of participatory governance activity in some societies. The requirement that FSC certifiers conduct stakeholder consultations seems to have stimulated the revitalization of community civic participation institutions in a number of forest communities in developing and transitioning societies, and in some cases to have opened up governmental decision-making processes. ${ }^{129}$ If the new PEFC requirement is implemented in a serious way, it may have a similar effect. The very process of creating certification programmes and regional or national standard-setting processes has stimulated public policy discussions in many countries. Finally, the

128 Overdevest, 'Codes of Conduct and Standard Setting in the Forest Sector: Constructing Markets for Democracy?', 59 Industrial Relations (2004) 172.

129 Tysiachniouk and Meidinger, 'Using Forest Certification to Strengthen Rural Communities: Cases from Northwest Russia' (forthcoming); Cashore, Gale, Meidinger, and Newsom, supra note 63. 
establishment of a constellation of forest certification programmes has created a larger participatory arena involving discussion and debate not only within programmes, but also among them, and in the broader arena of governments, environmental NGOs, forestry enterprises, and local and indigenous communities. In sum, the record of forest certification in facilitating both formal and informal public participatory processes in forestry policy-making appears to be fairly strong.

The rise of forest certification has also aided a structural expansion in who participates in forest policy-making. The traditional world of forest policy was a relatively closed system. In most countries government forestry agencies worked in close, comfortable relationships with foresters, landowners and the forest industry. Forest policy generally reflected what these interests wanted, occasionally as modified by the benign interventions of forestry researchers. The environmental movement brought interlopers into the field. Their efforts to change state policies were typically resisted, and their successes often limited to lawsuits setting aside legally indefensible forest policies. It was not possible to bring such law suits in most countries. The FSC did much to break open that closed structure by creating a parallel regulatory programme and threatening the brands of companies who depend on global product chains. The FSC was also able to draw upon ISO policies promoting broad stakeholder involvement in private standard setting.

Whether the industry based programmes will ever evolve to the kind of full 'balanced' participation of all stakeholders that the ISEAL guidelines envision is impossible to say at this time. But they have accepted in principle the need for broad stakeholder participation and begun to put it into practice, albeit in a carefully controlled way. It will not be easy for them to turn back.

\section{Revisiting Accountability}

To whom or to what is the global forest regulatory system, as manifested by forest certification, accountable? There is no single accountability structure in this system. Rather, multiple, mutually reinforcing accountability structures are operating at three conceptual levels. First, organizationally, there are the competing certification programmes, each seeking to demonstrate the capacity to certify proper forest management. These are in turn accountable to constituents of various kinds, including members, forestry operations, consumers, governments and public observers. Second, there is the overarching discourse of sustainable forest management to which they all profess allegiance. This discourse has several fixed elements, such as the requirement of sustained yield, but it also encompasses considerable debate about other values. Third, the various concepts of sustainability are embodied in the institutional structures described in Sections 2 and 3. These include documented rule-making processes which increasingly require reasoned responses to criticisms, structured adjudication by experts, increasing visibility through public information and consultation requirements, and competition in the market for forest certification, which is itself driven by a desire for public legitimacy. Like the discourse of sustainable forest management, these institutions seem to have some fixed and relatively irreversible elements, while at the same time being open to incremental revisions of various kinds. 
If the above is indeed a plausible outline of the accountability structure of forest certification, the challenge is how to conceptualize it in a way that facilitates further analysis and assessment. Its conceptual form is more synthetic and additive than theoretical and deductive, and its behavioural structure is both regular and creative. There are several possible approaches to this problem. The first is to conceive the accountability structure as the sum of its regulatory components. Colin Scott, for example, suggests viewing accountability in a given regulatory domain as the other side of the control structure. Since there are multiple control structures in many regulatory domains, there are multiple accountability structures. ${ }^{130}$ These are 'spontaneous' in the sense that they reflect the particular admixture of hierarchical authority, market competition, and community or network control present in a given social field. ${ }^{131}$ This approach has the considerable merit of recognizing the existence of 'mixed' modes of accountability and revealing the true complexity of many modern accountability arrangements. But it faces the problem of reconciling the various accountability structures, and explaining how they interact. Will they lead to overdetermined gridlocked relationships? If not, which ones will dominate, or how will they accommodate each other? From Scott's standpoint, these are empirical questions. Future research may indeed demonstrate a plethora of accountability structures built out of three or four basic control structures. It seems likely, however, that there are common unifying institutional and normative tendencies across the various regulatory fields, suggesting other dynamics at work than the modular interplay of elemental control structures based on who gets to decide. ${ }^{132}$

One approach that partially shares this intuition is that of Grant and Keohane, who categorize accountability mechanisms in terms of broader political structures based on either participation of affected parties or delegation from power holders. ${ }^{133}$ Again, however, accountability ends up being a question of who gets to decide. This approach has the pragmatic benefit of tracing authority to either broad public constituencies or specifically empowered actors. But it does not squarely encompass the dynamic competition to define and implement normatively oriented structures that are evident in the field of forestry regulation.

A second, more 'traditional' legal approach to accountability grows out of the 'soft' side of public law scholarship. Ultimately, it aims to assess the degree to which a regulatory system is true to its normative justifications. The immediate challenge is that

130 Scott, 'Spontaneous Accountability', in M.W. Dowdle (ed.), Public Accountability: Designs, Dilemmas and Experiences (2006, forthcoming).

131 Scott's analytical categories are based largely on Robert Goodin's distinctions among political, market, and civil society accountability structures: Goodin, 'Democratic Accountability: The Distinctiveness of the Third Sector', 64 Archives of European Sociology (2003) 359. These in turn reflect the foundational analytical traditions of Hobbes, Smith, and Rousseau. For a more diverse list of accountability mechanisms, see also Freeman, 'Collaborative Governance in the Administrative State', 45 UCLA Law Review (1997) 1.

132 The preliminary findings of the NYU IILJ Global Administrative Law project provide support for this view. See www.iilj.org.

133 Grant and Keohane, 'Accountability and Abuses of Power in World Politics', 99 Am Political Science Rev (2005) 1 . 
concepts such as sustainable forest management and sustainable development contain multiple normative justifications, and these may be somewhat at odds with each other as discussed above. Nonetheless, even such multivalent concepts may distinguish a domain in which actions are normatively supported from an area outside that domain in which they are not. Perhaps more importantly, this approach accommodates the normative elaboration and clarification that is evident in global forestry regulation.

The normative fidelity approach has more difficulty with processes that seem like normative change rather than elaboration. If protection of indigenous rights, for example, becomes a guiding norm for forestry when previously it was rejected and ridiculed, the standard move in this tradition is to attribute the change to an authoritative decision-maker, and to treat the change as legitimate or not depending on the status of that decision maker - that is, to flip back to the first mode of analysis described above. In practice, however, the authority of decision-makers seems to be quite contingent, and ever more so in the increasingly decentred regulatory system described in this paper. Policy-makers' authority, in other words, is often dependent on their responsiveness to emergent norms and standards, rather than the reverse - hence the decline and subsequent battle for re-establishment of traditional forestry authorities. The normative fidelity approach to accountability does not seem to have developed a persuasive account of this process, perhaps because it seeks to take norms as fixed reference points. A possibly important exception to this statement is the school of thought that has developed around Jürgen Habermas. But this school seems to focus so heavily on the internal rationality of normative dialogue as to miss the elements of competitive institutionalization, applied testing, and political manoeuvring described above. ${ }^{134}$ If these elements are important, it is necessary to look for a more complex model that includes competitive, self-interested actors and partially standardized institutions.

A third approach to accountability is to view the package of actors, norms and institutions as a larger system whose attributes are not reducible to the individual elements of the system. This is the approach that Charles Sabel and his colleagues are developing. ${ }^{135}$ They describe multi-centred, mutually adjusting, yet also institutionalized

134 See, generally, J. Habermas, Between Facts and Norms: A Discourse Theory of Law and Democracy (trans. W. Rehg, 1996). Habermas offers his own elaborate analysis of the polarity between who gets to make a decision and the normative justification of the decision in his distinction between 'facticity' (the positive promulgation of rules by politically authorized law-makers) and 'validity' (the claim that law is legitimate based on its rational acceptability which is in turn generated through non-instrumental discourse). For an effort in this direction that is much more attuned to the real world of modern regulatory practice, see Black, 'Regulatory Conversations', 29 J Law and Society (2002) 163.

135 E.g., Cohen and Sabel, 'Administrative Law and Global Politics: A Possibility for Democracy?', 38 NYU J Int'l L and Politics (2006, forthcoming); Dorf and Sabel, 'A Constitution of Democratic Experimentalism', 98 Columbia L Rev (1998) 267; Sabel, 'Theory of a Real Time Revolution' (manuscript on file with author); Simon, 'Toyota Jurisprudence', in G. de Bùrca and J. Scott (eds), Law and New Governance In the EU and the US (forthcoming). Sasha Courville has provided a description of how several of the individual certification programmes affiliated with ISEAL have sought to institute learning structures and cultures, and has also explored some of the tensions of the concept of a learning organization with concepts of principle agent accountability: Courville, 'Understanding NGO-Based Social and Environmental Regulatory Systems: Why We Need New Models of Accountability', in Dowdle (ed.), supra note 130. 
structures as learning systems capable of evolving both new values and new solutions, new goals and new strategies. This learning accountability perspective seems to match up fairly well with the emerging global forestry regulatory system described in this paper. The system seeks to clarify and sometimes modify policy goals in the course of implementation. It relies heavily on applied normative arguments backed up with reasons that are often based on practical experience. Certification programmes compete with each other by offering institutions that claim to efficiently assess and ultimately to legitimate forest management, and to do so in a way that is responsive to changing and sometimes only latent public values. To implement these claims the certification programmes rely on institutionalized procedures that provide public explanations for decisions as well as multiple (and multiplying) forums for public criticism. The programmes and their allies also criticize each other in larger public arenas, sometimes vehemently, while simultaneously recognizing a degree of mutual dependence and participation in a common project. Thus, forest certification seems to be instituting a continuing process of broad, cross-disciplinary, multi-interest internal and external surveillance and review. This system has led to frequent changes in substantive standards as well as rule-making and adjudication procedures as described in Sections 2 and 3. For the time being, this process shows no signs of slowing or stagnating.

While the above description seems to be an accurate empirical account of the forest certification system, the underlying nature of the learning accountability system, if indeed it is an accountability system, remains murky. At present it seems to be heavily procedural, focusing on participation, public justification, transparency, mutual monitoring and criticism, and competitive institutionalization. Yet the underlying tone of the learning accountability school seems to be functionalist. These kinds of experimental, open-ended, multi-centred, competitive regulatory systems seem to be good for society in the view of proponents because they are the most effective mechanisms for articulating its goals, testing them in practice, and revising them. Ultimately, then, the argument is that that they are good for society as a whole. ${ }^{136}$ For now though, at least in this arena, the learning accountability model faces two significant challenges. The first is the problem of distinguishing learning from drift and opportunism. It may turn out that the emerging forestry regulatory system shows significant progress in instituting environmental protection and sustainability but then again, it may not. It may simply provide a cover for long-term ineffectiveness and increased profits for a few narrow interests.

The second problem is to develop a clearer articulation of exactly how these systems answer to society and further its interests. For now the argument appears to be somewhat tautological. Learning regulatory systems answer to society because they

\footnotetext{
136 The concept of 'society' in forest certification remains contested. The founding understanding in the FSC programme was expansive, essentially global, while also including local communities with particular needs. The move to create stronger national programmes in the FSC, together with the centrality of national programmes in the PEFC, may indicate a tendency to pull back toward conceiving the global system as consisting of many 'societies', presumably national ones.
} 
are the best way of articulating and testing policies, and then disposing of outdated ones and implementing revised ones. At present it is intellectually defensible to see either an emerging functional learning accountability system or a gridlocked, disintegrating system of governmental accountability with nothing to replace it. It will be impossible to say which perspective is more accurate without first trying hard to elucidate the dynamics of an emergent accountability system. There are grounds for thinking that a persuasive account can be produced. Real optimists might even hope that the research process will contribute to the institutional criticism and eventual improvement of that system. 